\title{
Impact of High Altitude on Cardiovascular Health: Current Perspectives
}

\author{
Robert T Mallet' \\ Johannes Burtscher ${ }^{2,3}$ \\ Jean-Paul Richalet ${ }^{4}$ \\ Gregoire P Millet ${ }^{2,3}$ \\ Martin Burtscher (D) ${ }^{5,6}$ \\ 'Department of Physiology and Anatomy, \\ University of North Texas Health Science \\ Center, Fort Worth, TX, USA; \\ ${ }^{2}$ Department of Biomedical Sciences, \\ University of Lausanne, Lausanne, $\mathrm{CH}$ - \\ I0I5, Switzerland; ${ }^{3}$ Institute of Sport \\ Sciences, University of Lausanne, \\ Lausanne, CH-I0I5, Switzerland; \\ ${ }^{4}$ Laboratoire Hypoxie \& Poumon, UMR \\ Inserm UI272, Université Sorbonne Paris \\ Nord 13, Bobigny Cedex, F-93017, \\ France; ${ }^{5}$ Department of Sport Science, \\ University of Innsbruck, Innsbruck, \\ A-6020, Austria; ${ }^{6}$ Austrian Society for \\ Alpine and High-Altitude Medicine, \\ Mieming, Austria
}

Correspondence: Martin Burtscher Department of Sport Science, University of Innsbruck, Innsbruck, A-6020, Austria Email martin.burtscher@uibk.ac.at

\begin{abstract}
Globally, about 400 million people reside at terrestrial altitudes above $1500 \mathrm{~m}$, and more than 100 million lowlanders visit mountainous areas above $2500 \mathrm{~m}$ annually. The interactions between the low barometric pressure and partial pressure of $\mathrm{O}_{2}$, climate, individual genetic, lifestyle and socio-economic factors, as well as adaptation and acclimatization processes at high elevations are extremely complex. It is challenging to decipher the effects of these myriad factors on the cardiovascular health in high altitude residents, and even more so in those ascending to high altitudes with or without preexisting diseases. This review aims to interpret epidemiological observations in high-altitude populations; present and discuss cardiovascular responses to acute and subacute high-altitude exposure in general and more specifically in people with preexisting cardiovascular diseases; the relations between cardiovascular pathologies and neurodegenerative diseases at altitude; the effects of high-altitude exercise; and the putative cardioprotective mechanisms of hypobaric hypoxia.
\end{abstract}

Keywords: hypoxia, hypobaria, exercise, adaptation, acclimatization, conditioning

\section{Introduction}

Worldwide, about 400 million people reside at altitudes above $1500 \mathrm{~m}(\sim 5000 \mathrm{ft})^{1}$ and more than 100 million lowlanders visit areas above $2500 \mathrm{~m}(\sim 8000 \mathrm{ft})$ annually. ${ }^{2}$ Altitude ranges are commonly defined as high altitude $(1500-3500 \mathrm{~m}$; $\sim 5000-11,500 \mathrm{ft})$, very high altitude $(3500-5500 \mathrm{~m} ; \sim 11,500-18,000 \mathrm{ft})$, and extreme altitude $(>5500 \mathrm{~m} ;>18,000 \mathrm{ft}) .{ }^{3}$ Figure 1 shows the altitude ranges of some of the world's major mountainous regions.

At $5052 \mathrm{~m}(16,575 \mathrm{ft})$ above sea level, the world's highest city is La Rinconada, Peru (population c. 50,000 in 2020). The highest major city, El Alto, Bolivia

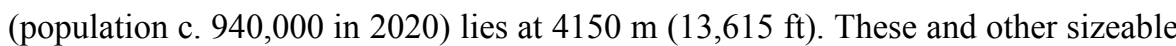
cities are in very high-altitude regions (Figure 1).

Whereas highlanders are chronically exposed to altitude and its associated climatic conditions, high-altitude travelers with or without pre-existing diseases, including tourists, climbers and trekkers, mine and road workers, porters and pilgrims, experience less protracted high-altitude exposures of hours to weeks. Climate changes progressively with increasing altitude, characterized by decreasing barometric pressure and partial pressure of inspired $\mathrm{O}_{2}$, declining ambient temperature and more intense ultraviolet solar radiation. ${ }^{4}$ Although all these conditions may contribute to the development and progression of chronic and acute high-altitude illnesses, the reduced partial pressure of oxygen (hypobaric hypoxia) is considered 


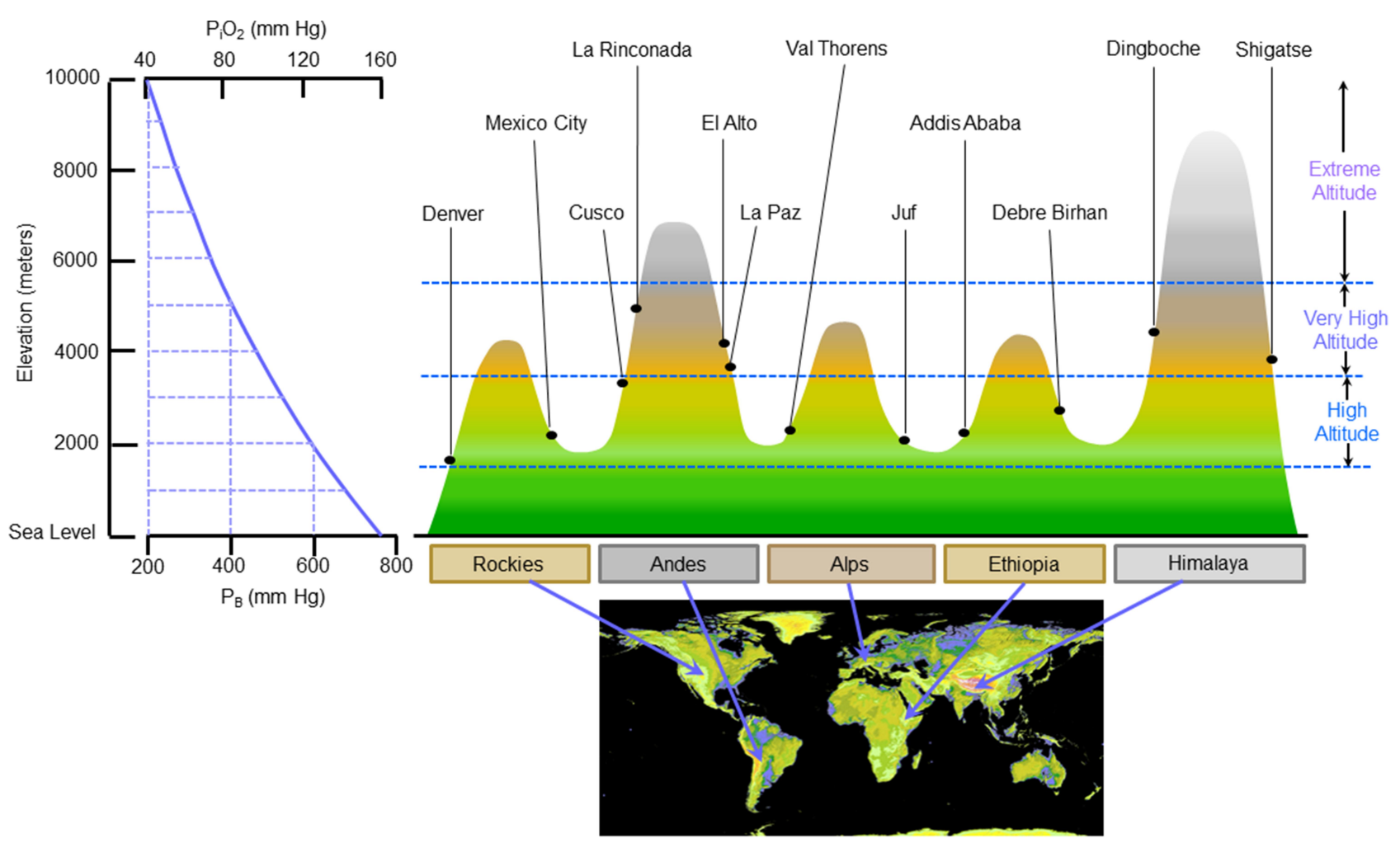

Figure I Partial pressure of inspired $\mathrm{O}_{2}\left(\mathrm{P}_{1} \mathrm{O}_{2}\right)$ is decreased in mountainous regions. Representative cities in major mountain ranges are shown. Notes: The map is courtesy of NASA/JPL-Caltech and adapted from NASA/JPL-Caltech. Aster Global Digital Elevation Map (GDEM) . Available at: https://asterweb.jpl.nasa. gov/images/GDEM-I0km-colorized.png. Accessed February 28, 2021. ${ }^{210}$

the primary cause. ${ }^{5-8}$ Genetic adaptations enable people to permanently live at altitudes up to $5000 \mathrm{~m}(\sim 16,400 \mathrm{ft}) .^{9,10}$ The highest altitude tolerable for prolonged sojourns is approximately $6000 \mathrm{~m}(\sim 19,700 \mathrm{ft})$, which mine workers on Volcán Aucanquilcha, Chile endured for up to two years (West 1986). Appropriate acclimatization strategies allow short-term stays at altitudes higher than $7000 \mathrm{~m}(\sim 23,000 \mathrm{ft})$ even for lowlanders, as demonstrated by many mountaineers. ${ }^{11}$

Besides genetic and lifestyle factors, chronic exposure to high-altitude environments may impact cardiovascular health, disease development and life-expectancy. ${ }^{12-18}$ While acute ascent to high altitudes may adversely affect cardiovascular health in lowlanders, particularly in those with pre-existing diseases, ${ }^{19,20}$ acclimatization diminishes this risk and hypoxia conditioning can even benefit and protect the cardiovascular system..$^{21,22}$ Not surprisingly, the interactions between the high-altitude climate, individual genetic, life-style and socio-economic factors, adaptation and acclimatization processes to various altitudes are extremely complex, restricting straightforward predictions of high-altitude sojourns on health-related outcomes concerning the cardiovascular system. Therefore, this review aims to interpret available epidemiological observations in high-altitude populations, present and discuss cardiovascular responses to acute and subacute highaltitude exposure in general and particularly in people with preexisting cardiovascular diseases, the relations between cardiovascular pathologies and neurodegenerative diseases at altitude, the effects of exercise at altitude and the putative cardioprotective mechanisms of adaptations to acute and chronic hypoxia.

\section{Living at High Altitude: Epidemiological Considerations}

Epidemiological data from populations permanently residing at high-altitude strongly indicate that environmental factors differently impact the development of cardiovascular diseases, depending on the altitude. ${ }^{17,18,23,24}$ While, for instance, lower mortality from cardiovascular diseases, stroke, cancer, and Alzheimer's disease was reported in high altitude regions in the Swiss ${ }^{18}$ and Austrian ${ }^{24}$ Alps and the western United States ${ }^{17,18,24,25}$ mortality from 
pulmonary morbidities (eg, emphysema, COPD) seemed to increase in high altitude residents. ${ }^{17,26}$ Thus, considering (patho) physiological responses to hypobaric altitude/ hypoxia, here we distinguish moderate altitude (1500 to $2500 \mathrm{~m})^{27}$ and high altitude from $2500 \mathrm{~m}$ to about $5000 \mathrm{~m}$, the highest permanent human residence. ${ }^{28}$ Data on the altitude-dependent prevalence of risk factors for cardiovascular diseases, eg, systemic hypertension, dyslipidemia and diabetes mellitus, and cardiovascular disease mortality may provide insights regarding the benefits vs detriments of living at moderate and high altitude, and the underlying mechanisms.

\section{Systemic Hypertension}

Reports of the effects of altitude on the prevalence of systemic hypertension, usually defined as systolic blood pressure $\geq 140 \mathrm{mmHg}$ and/or diastolic blood pressure $\geq 90$ $\mathrm{mmHg}$, are conflicting. A survey of 1631 Tibet inhabitants living at three different altitude ranges between 2700 and $4505 \mathrm{~m}$ revealed a decrease in hypertension prevalence from $40.6 \%$ to $20.4 \%$ from the lowest to the highest range, associated with decreasing body mass index (BMI). ${ }^{29}$ In contrast, systematic review of 8 cross-sectional studies totaling 16,913 individuals identified a close direct correlation between altitude and the prevalence of systemic hypertension in Tibet inhabitants, with a $2 \%$ increase in hypertension incidence per $100 \mathrm{~m}$ gain in altitude above $3000 \mathrm{~m} \cdot{ }^{30}$ Concordant with these findings, another metaanalysis of 40,854 Tibetans living at $\geq 2400 \mathrm{~m}$ reported increases in systolic and diastolic blood pressures of 17 and $9.5 \mathrm{mmHg}$, respectively, per $1000 \mathrm{~m}$ gain in elevation. ${ }^{31}$ However, in non-Tibetan, primarily Andean highlanders, blood pressure trended downward, albeit not significantly, with increasing altitude. ${ }^{31}$

The observed differences between Andean and Tibetan highlanders may represent the vascular consequences of divergent adaptation patterns. ${ }^{32}$ In Andean highlanders, chronic mountain sickness and pulmonary artery hypertension are more prevalent, while systemic blood pressure and cerebral blood flow are lower than in Tibetan highlanders. ${ }^{33}$ The mechanisms underlying these differences may primarily relate to regulation of gene expression, eg, activation of hypoxia-responsive gene transcription by hypoxia-inducible factors. Notably, a recent study suggested that conventional blood pressure measurement may underestimate hypertension prevalence in Andean highlanders, while ambulatory blood pressure monitoring unmasks hypertension. ${ }^{34}$ Collectively these studies identify genetic adaptations, lifestyle and climatic factors as pivotal determinants of blood pressure responses to living at high altitude. Decreased appetite and caloric intake, and increased energy expenditure due to low ambient temperature, likely contribute to lower BMI and reduced risk of hypertension at high altitude., ${ }^{4,29}$

\section{Dyslipidemia}

Studies of residents of Lhasa, Tibet $(3660 \mathrm{~m})$ demonstrated high prevalence of hypertriglyceridemia in males and hypercholesterolemia in both sexes, and lower circulating high-density lipoprotein (HDL) cholesterol contents in females. ${ }^{35}$ Similar findings were reported from the moderate-altitude (1500-2500 m) Yunnan-Kweichow Plateau in Southwestern China, with a higher prevalence of hyperlipidemia, hypercholesterolemia, and hypertriglyceridemia in males, and slightly lower HDL cholesterol and higher LDL cholesterol values in females. ${ }^{36}$ These authors attributed the prevalence of hyperlipidemia mainly to unhealthy living habits associated with obesity. By contrast, highly educated adults living in Riobamba, Ecuador $(2754 \mathrm{~m})$ had a lower prevalence of metabolic syndrome, hypercholesterolemia and hyperglycemia than lowlanders living on the Ecuadorian coast, ${ }^{37}$ which may have been attributable to reduced appetite and selfreported lower energy intake at altitude. Socio-cultural and socio-economic factors explained inter-individual variation of hypercholesterolemia in the Swiss alpine population, while no specific altitude effects were detected. ${ }^{38}$ Again, genetic, life-style, and socio-economic factors are probably more important than altitude-related low temperature and increased energy expenditure.

\section{Diabetes}

A cross-sectional study of 284,945 US residents revealed an inverse association (adjusted for multiple confounders) between altitude and diabetes prevalence. ${ }^{39}$ Compared to low-altitude $(0-499 \mathrm{~m})$ residents, the odds ratio for diabetes was 0.95 (95\% CI: $0.90-1.01)$ between 500 and $1499 \mathrm{~m}$, and $0.88(0.81-0.96)$ between 1500 and $3500 \mathrm{~m}$. Notably, the inverse association was only true for men $(0.84 ; 0.76-0.94)$, not women $(1.09 ; 0.97-1.22){ }^{39}$ Data from Tibetans living between 2900 and $4800 \mathrm{~m}$ suggested that altitude-related hypoxemia and polycythemia were closely associated with glucose intolerance and diabetes mellitus after adjusting for lifestyle. ${ }^{40}$ As mentioned above, hyperglycemia was less prevalent in Ecuadorian Altiplano residents $(\sim 2770 \mathrm{~m})$ than in 
lowlanders. ${ }^{37}$ As diabetes type 2 is closely associated with obesity, lower obesity prevalence (adjusted for multiple covariates including physical activity) with increasing altitude may largely explain the reduced diabetes risk in highlanders, ${ }^{41}$ underscoring the importance of altitude and cold on caloric intake-expenditure balance and BMI.

\section{Chronic Mountain Sickness (CMS)}

Chronic mountain sickness (CMS), also known as Monge's disease, is a syndrome affecting about $5 \%$ to $10 \%$ of the 140 million people permanently living at high altitude. ${ }^{42}$ It seems to be a consequence of progressive loss of ventilatory rate, increasingly observed with aging and resulting in excessive hypoxemia and polycythemia ( $\mathrm{Hb} \geq 19 \mathrm{~g} / \mathrm{dL}$ for women and $\mathrm{Hb} \geq 21 \mathrm{~g} / \mathrm{dL}$ for men). ${ }^{43}$ This syndrome is frequently associated with pulmonary hypertension, and in advanced cases, it may progress to cor pulmonale and congestive heart failure. ${ }^{43}$ Periodic travel to lower altitudes is recommended for those with rather mild symptoms, but severe cases should move permanently to lower altitudes. ${ }^{44}$

\section{Mortality from Cardiovascular Diseases}

In contrast to the inconsistent findings regarding the altitude-dependent prevalence of risk factors for cardiovascular diseases, data on the cardiovascular mortality risk are more consistent, at least for the moderate altitude regions of the Alps. Increasing altitude was associated with lower coronary heart disease and stroke mortality rates for both sexes in Switzerland ${ }^{18}$ and lower mortality from coronary artery disease, male colorectal cancer and female breast cancer in Austria. ${ }^{24}$ Faeh and colleagues reported respective $22 \%$ and $12 \%$ reductions in mortality from coronary heart disease and stroke per $1000 \mathrm{~m}$ gain in elevation. ${ }^{18}$ Adjusted analysis revealed that the decreased mortality probably was not due to reductions in classic cardiovascular risk factors but instead might be explained by geographic factors like altitude/hypoxia and/or the effects of solar radiation on Vitamin D. Accordingly, the Austrian study revealed reductions of coronary artery disease mortality at $1000-2000 \mathrm{~m}$ vs $<250 \mathrm{~m}$ of $28 \%$ in men and $31 \%$ in women. ${ }^{24}$ These findings are concordant with life expectancy increases of $1.2-3.6$ years in men and $0.5-2.5$ years in women residing in US counties with mean altitudes $>1500 \mathrm{~m}$ vs residents of counties within $100 \mathrm{~m}$ of sea level. ${ }^{17}$

Detrimental effects of altitude residence on the risk of heart disease and mortality only rarely have been reported.
Virues-Ortega and colleagues demonstrated increased overall mortality at higher altitudes, most pronounced over $3000 \mathrm{~m}$, possibly due to more extreme climate conditions at those altitudes. ${ }^{5}$ While risk factors for cardiovascular diseases are not uniformly affected by high altitude conditions, there is agreement on the beneficial effects of moderate if not extreme altitudes on the mortality risk from cardiovascular diseases. It thus seems likely that mild environmental stimuli (eg, hypoxia, cold, ultraviolet radiation) at moderate altitude will promote conditioning associated with favorable outcomes, vs the likely detrimental effects of more intense stimuli at extreme altitudes. ${ }^{16}$ However, it is important to mention that altitude-related lifestyle behaviors very likely contribute to the observed beneficial effects of living at "moderate altitudes", ie, below $2000 \mathrm{~m}$, on the cardiovascular and cerebrovascular systems.

\section{Acute and Subacute Effects of High-Altitude Exposure}

Individuals rapidly ascending from low to high altitudes $(>2000 \mathrm{~m})$ are at risk to develop acute mountain sickness (AMS), which is characterized by headache as the predominant symptom, commonly accompanied by nausea, lack of appetite, vomiting, insomnia, dizziness, and/or fatigue. ${ }^{45}$ The AMS prevalence was shown to increase from $7 \%$ at $2200 \mathrm{~m}$ to $38 \%$ at $3500 \mathrm{~m}$, and to $52 \%$ when rapidly ascending to $4559 \mathrm{~m}$ in the alpine regions, ${ }^{45,46}$ and a similar risk has been derived from Chinese highland military medical records. ${ }^{47}$ Usually, AMS symptoms resolve during the first days at altitude, but may in rare cases progress to life-threatening diseases such as high-altitude cerebral edema (HACE) and/or high-altitude pulmonary edema (HAPE). A HACE prevalence of $0.98 \%$ has been reported in a cohort of 1326 European individuals sojourning to $4000 \mathrm{~m},{ }^{48}$ while $\mathrm{Wu}$ and colleagues found a prevalence of $0.28 \%$ among 14,000 Asian railroad workers who travelled from lowland China to Tibet $(3500-5000 \mathrm{~m}) .{ }^{49}$ In a population of unknown HAPE history, the HAPE incidence was $0.2 \%$ when climbing to $4500 \mathrm{~m}$ within 4 days, but increased to $6 \%$ when ascending to this altitude in only 1 to 2 days. ${ }^{20}$ Besides hypoxia at high altitude, other risk factors like extreme temperatures must be considered. For instance, while military troops have developed appropriate acclimatization schedules for hypobaric hypoxia, the very low temperature, eg, down to $-55^{\circ} \mathrm{C}$ during the winter time in the Western Himalayas, still remains an important health 
challenge, even in young, fit and healthy soldiers. ${ }^{50}$ Adverse effects of acute high altitude exposure are largely avoidable by proper acclimatization, ie, low ascent rates, or the use of appropriate pre-acclimatization strategies. ${ }^{45}$ A precise understanding of physiological responses to acute high altitude is required to optimize the individual acclimatization process and to avoid potentially associated risks to the cardiovascular system.

Declining partial pressure of oxygen, $\mathrm{PO}_{2}$, parallels decreasing barometric pressure $\left(\mathrm{P}_{\mathrm{B}}\right)$ with increasing altitude. For instance, at $2360 \mathrm{~m}$, the altitude of Addis Ababa, Ethiopia, $\mathrm{P}_{\mathrm{B}}$ and $\mathrm{PO}_{2}$ are $75 \%$ of those at sea level, and at $5052 \mathrm{~m}$, the altitude of La Rinconada, Peru they are only about $53 \%$ of the respective sea level pressures (Figure 1). As $\mathrm{PO}_{2}$ in the inspired air $\left(\mathrm{P}_{\mathrm{i}} \mathrm{O}_{2}\right)$ declines, so does $\mathrm{PO}_{2}$ in the alveoli $\left(\mathrm{P}_{\mathrm{A}} \mathrm{O}_{2}\right)$ and systemic arterial blood $\left(\mathrm{P}_{\mathrm{a}} \mathrm{O}_{2}\right)$, as does arterial oxygen saturation $\left(\mathrm{S}_{\mathrm{a}} \mathrm{O}_{2}\right)$. Hypoxemia activates peripheral chemoreceptor afferents of the carotid bodies increasing minute ventilation and, via sympathetic activation, heart rate ${ }^{51}$ and, thus, cardiac output. Collectively, these ventilatory and cardiac responses partially counteract the diminished oxygen supply at high altitude. ${ }^{21,51-55}$ Generally, the rising sensitivity of the peripheral chemoreceptors over days at altitude increases ventilation, but ventilatory acclimatization differs among individuals. ${ }^{56}$ Hyperventilation improves oxygenation but lowers $\mathrm{P}_{\mathrm{a}} \mathrm{CO}_{2}$ producing alkalemia. The resulting decrease of renal tubular $\mathrm{H}^{+}$secretion compensates for the respiratory alkalosis by enhancing urinary excretion of bicarbonate. ${ }^{57,58}$ Elevated diuresis also causes hemoconcentration, on the one hand reducing plasma volume and lowering stroke volume and, on the other hand, increasing arterial oxygen content and oxygen delivery to tissues at a given cardiac output. ${ }^{55,59}$ As acclimatization progresses, cardiac output returns to baseline but heart rate remains elevated because of the lower stroke volume (Figure 2). ${ }^{55}$

Hypoxic pulmonary vasoconstriction, another physiologic hallmark of acute high-altitude ascent, elevates pulmonary artery pressure, and this response reportedly is particularly profound in the elderly. ${ }^{53,62}$ Systemic blood pressure also increases upon initial ascent to altitude, primarily due to pronounced sympathetic activation, at least in men. ${ }^{59,61}$ While ventilation and heart rate, pulmonary and systemic blood pressures, and sympathetic activity remain elevated with acclimatization, stroke volume decreases, cardiac output returns to baseline, and arterial oxygen saturation improves (Figure 2). ${ }^{55,59,62}$ Notably, all these responses vary considerably between individuals and do not completely compensate for the reduced $\mathrm{P}_{\mathrm{i}} \mathrm{O}_{2}$, especially at extreme altitudes.

Despite all these changes, in healthy individuals, myocardial oxygen supply and left ventricular function are

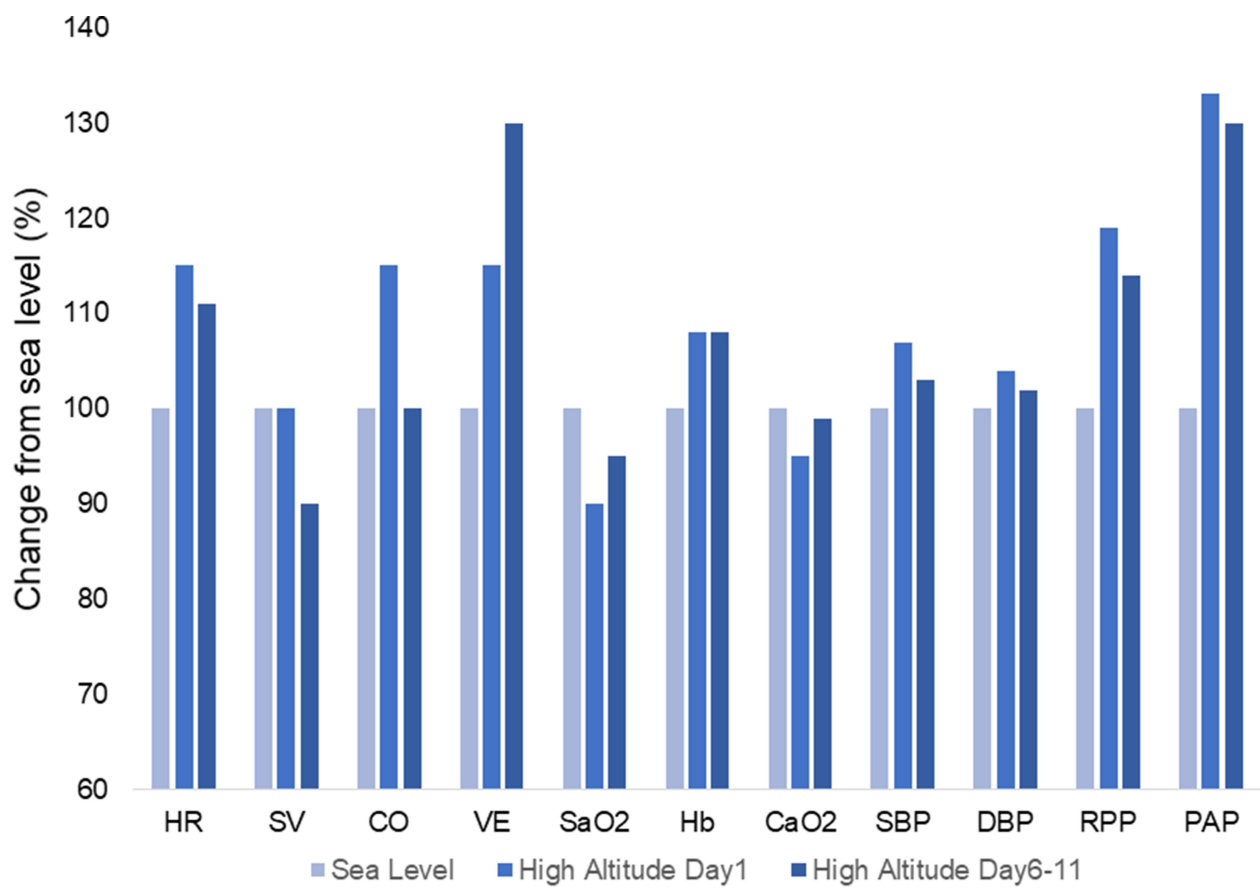

Figure 2 Changes of resting cardiovascular parameters when acutely exposed to high altitude and during acclimatization. Notes: Bbased on data reported in references 55 and ${ }^{62-65}$. From left to right.

Abbreviations: $\mathrm{HR}$, heart rate; $\mathrm{SV}$, stroke volume; $\mathrm{CO}$, cardiac output; $\mathrm{VE}$, minute ventilation; $\mathrm{SaO}_{2}$, arterial oxygen saturation; $\mathrm{Hb}$, hemoglobin concentration; $\mathrm{CaO}$, arterial oxygen content; SBP, DBP, systolic and diastolic blood pressure; RPP, rate pressure product; PAP, pulmonary artery pressure. 
maintained at rest and even during maximal exercise at high altitude. ${ }^{55,66}$ Moreover, moderate and high altitude are also well tolerated by healthy elderly subjects, ${ }^{21,67}$ but may become detrimental in those suffering from cardiovascular diseases. ${ }^{19,60}$

\section{Cardiovascular Changes in Patients with Preexisting Cardiovascular Diseases}

In cardiac patients, hypoxemia might be detrimental even at sea level, although there is very little evidence of aggravated cardiovascular diseases at least at low or moderate altitude. A list of recommendations from the European Society of Cardiology can serve as a basis for clinical practice. ${ }^{68}$ However, as yet the biomedical literature provides no clinical evidence regarding the risk of all types of cardiovascular diseases at moderate or high altitude. $^{19,69,70}$ Nevertheless, the basic knowledge of the physiology of hypoxia and of the pathophysiology of cardiac or vascular diseases allows us to propose four simple guidelines to help practitioners make decisions and give appropriate advice to their cardiac patients with regard to altitude sojourns.

- Patients suffering from any diseases that may be aggravated by an overactivation of the adrenergic system (tachyarrhythmias) might be at risk at high altitude.

- Patients suffering from any diseases associated with pulmonary hypertension will be at high risk even at moderate altitude.

- Patients suffering from any diseases presenting, even at sea level, a certain degree of arterial hypoxemia (eg, increased right-to-left shunt) will be at risk at high altitude.

- For a given absolute power output during exercise, the heart rate (and therefore myocardial energy demand) increases with altitude, lowering the ischemic threshold in coronary patients.

The following advice can be given as a function of the preexisting disease.

\section{Arrhythmias}

Although rapid ascent to high altitude may increase the frequency of supraventricular and ventricular arrhythmias in patients with underlying heart disease, ${ }^{60,71,72}$ no demonstrable clinical impact has been found. ${ }^{73}$ However, it is reasonable to limit the access to altitude above $2500 \mathrm{~m}$ for patients with severe arrhythmias associated with underlying heart disease.

\section{Pulmonary Hypertension}

Preexisting pulmonary hypertension at sea level may deteriorate at even moderate altitude, regardless of the origin of the hypertension. Patients with congenital or acquired anomalies of the pulmonary circulation are also at high risk. $^{74,75} \mathrm{~A}$ transient hypoxic insult to the pulmonary circulation during the first postnatal week leaves a persistent imprint which, when activated by hypobaric hypoxia, predisposes to pulmonary hypertensive responses in adulthood. $^{76}$ Nevertheless, a recent pilot study showed that patients with pulmonary hypertension can safely adapt to a moderate altitude of $2048 \mathrm{~m}^{77}$

\section{Right-to-Left Shunt}

Right-to-left atrium shunting through a patent foramen ovale (PFO) might be aggravated in hypoxic conditions due to increased pressures in the pulmonary artery and the right heart. PFO was found to be present in $56 \%$ of patients susceptible to HAPE vs $11 \%$ of non-susceptible subjects. ${ }^{78,79}$ Patients with cyanotic congenital heart diseases may be at heightened risk at even moderate altitude. $^{80}$

\section{Coronary Artery Disease}

It is reasonable to assume that in patients with a reduced coronary reserve, the decrease in oxygen availability due to altitude exposure will increase the risk of myocardial ischemia. However, the literature shows no evidence of increased incidence of acute myocardial ischemic events at low and moderate altitude. ${ }^{60,72,81,82}$ In nine men with coronary artery disease, clinical or electrocardiographic signs of ischemia occurred at lower workloads at $3100 \mathrm{~m}$ than at $1600 \mathrm{~m}$, although heart rate and heart rate $\mathrm{x}$ systolic blood pressure (rate pressure product, RPP) at the onset of angina were similar at the two altitudes. $^{72}$ These findings suggest that patients should limit their activity at high altitude by controlling their heart rate $(70-85 \%$ of the ischemic threshold rate at lower altitude) rather than their workload. A rapid ascent and submaximal exercise proved to be safe at an altitude of $3454 \mathrm{~m}$ for low-risk patients with normal low-altitude exercise stress tests 6 months after revascularization for an acute coronary event. ${ }^{83}$ Mortality from coronary heart disease, from 1990 to 2000, in men and women living at $259-1960 \mathrm{~m}$ decreased by $22 \%$ per $1000 \mathrm{~m}$ ascent. The 
consistently protective effect of living at higher altitude on coronary heart disease and stroke mortality increased after adjustment for potential confounders. ${ }^{18}$

\section{Congestive Heart Failure}

Very few studies are available about heart failure at high altitude. ${ }^{69,73,84}$ However, in 38 patients with a mean left ventricle ejection fraction of $35 \%$, acute exposure to $3000 \mathrm{~m}$ in a hypobaric chamber induced no signs of myocardial ischemia, arrhythmias, or acute heart failure. ${ }^{84}$ Altogether, it seems that up to $3000 \mathrm{~m}$, there is no substantial increase in cardiovascular risk for patients with stable, compensated heart failure. ${ }^{73,84,85}$ Corroborating this conclusion, a short-term high-altitude exposure at $3454 \mathrm{~m}$ was well tolerated in patients with stable heart failure. ${ }^{83}$

\section{Systemic Hypertension}

The systemic circulation at high altitude is affected by two opposing phenomena: local hypoxia-induced vasodilation and general sympathetic-induced vasoconstriction. The relative impact of these two factors on local perfusion and systemic arterial pressures varies considerably among subjects. ${ }^{73,83,86,87}$

In well-controlled hypertensive patients, no significant increase in systemic blood pressure is usually observed and no complications of systemic hypertension at high altitude have been reported. ${ }^{87}$ Moreover, in 37 young adult men with stage 1 hypertension, completing a 20day program of intermittent, normobaric hypoxia (inspired $\mathrm{O}_{2}$ fraction $0.1 ; 4-10$ daily cycles of 3 min hypoxia and 3 min room air breathing) lowered systolic and diastolic arterial pressures by 22 and $17 \mathrm{~mm} \mathrm{Hg}$, respectively. ${ }^{88}$ Moreover, the decrease in systemic arterial pressure persisted at least 3 months after the hypoxia program in $85 \%$ of the subjects. Concordant with these results, no symptomatic episodes of hypertension were recorded in a cohort of 672 trekkers (60 of them with systemic hypertension), using conventional blood pressure measurements. ${ }^{89}$ Therefore, no adverse effects are anticipated when patients with well-controlled hypertension are exposed to high altitude.

In summary, the literature is still sparse concerning cardiac diseases and tolerance to high altitude. However, it seems that patients with cardiac arrhythmias, pulmonary hypertension and right-to-left shunts should avoid an exposure to altitudes above $2500 \mathrm{~m}$. In the case of coronary disease and congestive heart failure, the advice should depend on the functional state of the patient. Patients with well-controlled systemic hypertension are not at higher risk at high altitude.

\section{Relation Between Cardiovascular Pathologies and Neurodegenerative Diseases at Altitude}

Cardiovascular risk factors, such as total serum cholesterol or high systolic blood pressure, ${ }^{90}$ are major risk factors for cognitive decline, the development of dementia and other age-related neurological diseases. ${ }^{91-94}$ The brain's particular vulnerability to perfusion deficits and its specific blood supply requirements, including increased on-demand perfusion with neuronal activation, highly selective permeability across the blood brain barrier, and vulnerability of the cerebral microvasculature, necessitate a particularly delicate regulation of cerebral blood flow. ${ }^{95}$

Diminished oxygen supply to the brain - for example as a consequence of hypoxic conditions in high altitude - jeopardizes brain function and can acutely cause cognitive impairments, ${ }^{96-101}$ mood alterations ${ }^{102,103}$ and altituderelated conditions impacting the brain, such as acute mountain sickness or high altitude cerebral edema. ${ }^{104}$ Severe hypoxia may even trigger parkinsonism-like symptoms ${ }^{105-107}$ or global amnesia. ${ }^{108}$ Brain deoxygenation at altitude reportedly is more pronounced during physical exercise ${ }^{109}$ and more persistent than peripheral deoxygenation. ${ }^{110}$

Several systemic, brain-specific and cellular physiological adaptations are implemented to mitigate the detrimental consequences of hypoxia on the brain. ${ }^{111-119}$ As described above, peripheral chemoreceptor-induced hyperventilation $^{120}$ and cardiac output ${ }^{121,122}$ enhance systemic and brain oxygenation. Metabolic autoregulation and neurovascular coupling ${ }^{95,123}$ acutely modulate the cerebral blood flow in response to hypoxia. This modulation can vary across different cerebral arteries; thus, Feddersen et $\mathrm{al}^{124}$ reported increased blood flow velocity in anterior and middle cerebral arteries of ascending mountaineers, while blood flow velocity in the posterior cerebral artery declined. In rats, acute hypoxia exposure only transiently increases cerebral blood flow, ${ }^{125}$ while chronic hypoxia triggers erythropoiesis ${ }^{125}$ as well as angiogenesis ${ }^{125}$ that increases brain capillary densities. ${ }^{126,127}$ At the cellular level, responses to hypoxia are mediated by numerous biochemical adaptations $^{111}$ including downregulation of $\mathrm{O}_{2}$-dependent reactions, promotion of glycolysis, ${ }^{114}$ 
protection of mitochondria, ${ }^{115}$ boosting of antioxidant defense mechanisms ${ }^{113,116}$ and attenuation of cell death. ${ }^{117}$

These effects of hypoxia exposure suggest its potential application to counteract age-related and pathological alterations of cerebral blood flow and cerebrovascular alterations. The role of aging-related cerebrovascular deterioration and cerebral blood flow dysregulation on cognitive dysfunction has been reviewed by Toth et $\mathrm{al}^{95}$ and pathological alterations in neurovascular function are proposed to be key mechanisms in the pathogenesis of Alzheimer's disease. ${ }^{128}$

The cardiovascular adaptations to hypoxia, and in particular intermittent application of hypoxia (ie, hypoxia conditioning), improve cerebral blood flow and cerebrovascular function (Figure 3), ${ }^{90,129}$ in a manner that enhances cerebral oxygenation. ${ }^{130,131}$ Intermittent hypoxia also increases brain capillary densities, although to a smaller extent than chronic hypoxia. ${ }^{132}$ Hypoxia-induced angiogenesis may particularly improve neurovascular coupling. ${ }^{126,133}$

In support of the application of hypoxia to improve brain function, several recent clinical trials have reported improved cognitive function following intermittent hypoxia therapies, for example, in generally healthy older adults ${ }^{134-136}$ or those with mild cognitive impairment, ${ }^{137,138}$ a risk factor for the subsequent development of dementia. Although experimental data on hypoxia conditioning in patients with age-related neurological diseases is limited, the potential of such therapeutic strategies in these diseases is becoming increasingly acknowledged. ${ }^{119,139,140}$ Preclinical studies in rodents further emphasize this potential, for example, in models of Alzheimer's disease ${ }^{141,142}$ and Parkinson's disease. $^{143}$

Epidemiological studies on the effect of altitude of residence on brain function are conflicting, due in part to socioeconomic confounders. While reduced memory capacities were reported in young Tibetans living at $3650 \mathrm{~m}$ vs low altitude residents ${ }^{144}$ and subtle impairments in speed of neurocognitive functions were reported in Andean high vs low altitude residents of different age groups, ${ }^{145}$ no adverse cognitive effects were found in adolescent Bolivian high altitude $(3700 \mathrm{~m})$ residents. ${ }^{146}$ Thielke et $\mathrm{al}^{25}$ even report reduced Alzheimer's disease mortality at higher altitudes of residence (up to $1800 \mathrm{~m}$ ) in California.

More research is required to define the effects of altitude of residence on cognitive functions, particularly in association with neurodegenerative diseases. Nevertheless, controlled hypoxia interventions are promising therapeutic approaches to mitigate age- or disease-related cognitive decline.

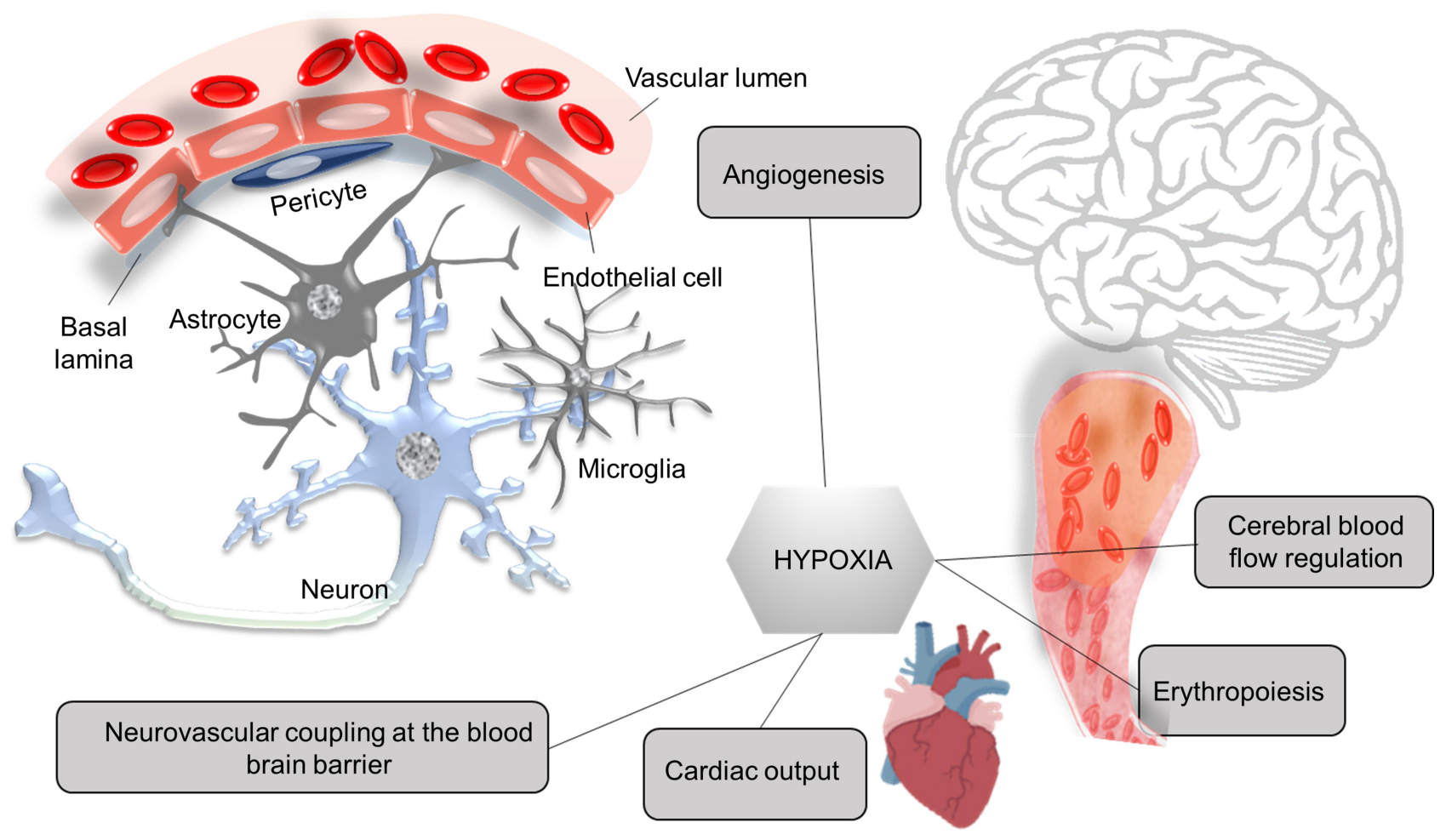

Figure 3 Hypoxia-evoked adaptations improve cardiovascular determinants of brain oxygenation. 


\section{Effects of Hypoxia on Aerobic Exercise, and Vice Versa}

This section presents a brief description of the effects of hypobaric and normobaric hypoxia on responses to maximal and submaximal exercise, and then discusses some potential benefits and limitations of exercising in hypoxia.

\section{Maximal Responses to Exercise in Altitude}

At altitude, the decreased $\mathrm{PO}_{2}$ and resultant hypoxemia ${ }^{147}$ lower maximal oxygen uptake $\left(\mathrm{VO}_{2 \max }\right)$ by approximately 6-7\% per $1000 \mathrm{~m}$ increase at altitude. ${ }^{148}$ This altered $\mathrm{O}_{2}$ intake is the main factor limiting aerobic performance at altitude vs sea level. Of interest, the decrement in endurance exercise performance is less severe in normobaric hypoxia imposed by reductions in the inspired fraction of oxygen $\left(\mathrm{F}_{\mathrm{I}} \mathrm{O}_{2}\right)$ than equivalent reductions in $\mathrm{PO}_{2}$ due to decreased barometric pressure, ie, hypobaric hypoxia ${ }^{149}$ since the intensity of the normobaric hypoxia stimulus may be lower, although this point is debated. ${ }^{150,151}$ In either case, maximal cardiac output declines since both maximal stroke volume and heart rate are lower during hypoxia, whether due to decreased barometric pressure or $\mathrm{F}_{\mathrm{I}} \mathrm{O}_{2}$.

Maximal heart rate $\left(\mathrm{HR}_{\max }\right)$ declines at altitude. ${ }^{152,153} \mathrm{It}$ was argued that this decrease in $\mathrm{HR}_{\max }$ is only observable above a threshold of $2000-3500 \mathrm{~m}^{147,154}$ corresponding to the altitude used in training and/or rehabilitation. However, this decrease was reported already at low altitude $(<1000 \mathrm{~m}) .{ }^{155}$ Of clinical interest, the decrease in $\mathrm{HR}_{\max }$ is lower in normobaric than in hypobaric hypoxia. ${ }^{156}$

\section{Submaximal Responses to Exercise at Altitude/in Hypoxia}

During submaximal exercise, HR is greater and stroke volume lower at a given exercise intensity in hypoxia vs normoxia. Since resting HR increases while $\mathrm{HR}_{\max }$ declines with altitude, HR reserve is attenuated, which the HR-based calculations of exercise intensity described below must take into account. The relationships between cardiac output, workload and $\mathrm{VO}_{2}$ are preserved at all submaximal intensities, but reach their maxima at lower $\mathrm{VO}_{2}$ and cardiac output ${ }^{55}$ implying that altitude does not affect $\mathrm{O}_{2}$ utilization efficiency. The mechanisms for the increased HR are still debated but sympathetic vasoconstrictor activity and the resultant higher vascular resistance likely predominate.

\section{Therapeutic Exercising in Hypoxia for Cardiovascular Pathologies}

Heart rate monitoring is very common and clinically safe for patients. ${ }^{157} \mathrm{An}$ important aspect when prescribing exercise in cardiovascular patients is the determination of exercise intensity. Generally, the recommended intensity is based on the percentage of $\mathrm{HR}_{\max }{ }^{158,159}$ and is estimated as $60-70 \%$ of $\mathrm{HR}_{\max }$ in patients. The hypoxic decrease in $\mathrm{HR}_{\max }$ described above has clinical implications and requires adjustment of the exercise intensity at altitude since a given percentage of $\mathrm{HR}_{\text {max }}$ measured in normoxia would overestimate the target exercise intensity at altitude, with the risks of excessive fatigue or decreased adherence to training sessions.

Exercising in hypoxia, even at submaximal intensity, leads to a 'compensatory' vasodilatation, relative to the same exercise intensity in normoxia, ${ }^{160}$ that, by augmenting blood flow, limits the decrement of oxygen delivery to the active muscles. Nitric oxide (NO) appears as the main vasodilator generated by the endothelium ${ }^{161}$ even if several other vasoactive substances are also involved in this compensatory vasodilatation during hypoxic exercise. Of interest, this enhanced exercise hyperemia is greater at high altitude and augmented by increased exercise intensity. ${ }^{160,162}$ By this mechanism, hypoxia may potentiate exerciseinduced vascular adaptations such as vasodilation, ${ }^{163}$ potentially benefiting patients with vascular dysfunction as in peripheral artery diseases.

Vasoconstriction in vascular beds of contracting muscles is blunted when exercise is performed in hypoxia, to the extent that vasodilation may prevail. ${ }^{160}$ This functional sympatholysis may have additional effect with benefits for hypertensive subjects: the post-exercise hypotensive effect due to a reduction in total peripheral resistance is enhanced in hypoxia suggesting a larger hypotensive effect of exercise in hypoxia than in normoxia, ${ }^{164}$ as suggested above.

Altogether, the health benefits of hypoxic exercise in cardiovascular patients are mediated by improved responsiveness of the vascular system, representing the balance of two opposing mechanisms: peripheral vasodilation and sympathetically mediated vasoconstriction. The effects of exercising at altitude in specific patients depend upon several factors, including the patient's predisposition to exercise, the intensity of the hypoxic dose (altitude, exposure duration, rate of ascent, intermittent 
pattern) and attainment of adequate exercise intensity (but not limited to moderate intensity). Optimizing the benefits vs risks requires a patient-specific regimen and monitoring.

\section{Cardioprotective Mechanisms of Hypobaric Hypoxia}

By generating reactive oxygen species (ROS), intensifying sympathetic stimulation of the heart and lowering intracellular $\mathrm{PO}_{2}$, systemic hypoxia mobilizes diverse gene programs expressing myriad cytoprotectants including antioxidant, anti-inflammatory and glycolytic enzymes, antiapoptotic factors and $\mathrm{Ca}^{2+}$ transporters, which collectively defend cardiomyocytes from ischemic injury (Figure 4).

Defining hypobaric hypoxia's cardioprotective mechanisms at the cellular level requires invasive analyses of gene expression, proteins, metabolites and organelles, which are not ethically feasible in humans under most circumstances.
Consequently, information on the molecular underpinnings of hypoxia-induced cardioprotection is gleaned from studies in animals, primarily rodents. Many such studies utilize intermittent, not sustained, hypoxia involving brief hypobaric exposures or cyclic exposures to normobaric, hypoxic gas. Although intermittent hypoxia's cardinal features differ from those of chronic hypoxia, information on intermittent hypoxia's cytoprotective mechanisms likely applies at least qualitatively to sustained hypoxia, too.

\section{Reactive Oxygen Species Induction of Antioxidant Genes}

Hypobaric hypoxia elicits ROS formation in humans. After $48 \mathrm{~h}$ at $4300 \mathrm{~m}$ altitude, lowlanders showed increased serum and urinary concentrations of the lipid peroxidation products $\mathrm{F}_{2}$ - and 8-isoprostanes. ${ }^{165}$ In men exposed to $5500 \mathrm{~m}$ simulated altitude for $4 \mathrm{~h}$, arterial $\mathrm{O}_{2}$ saturation fell by $45 \%$, serum concentrations of the ROS

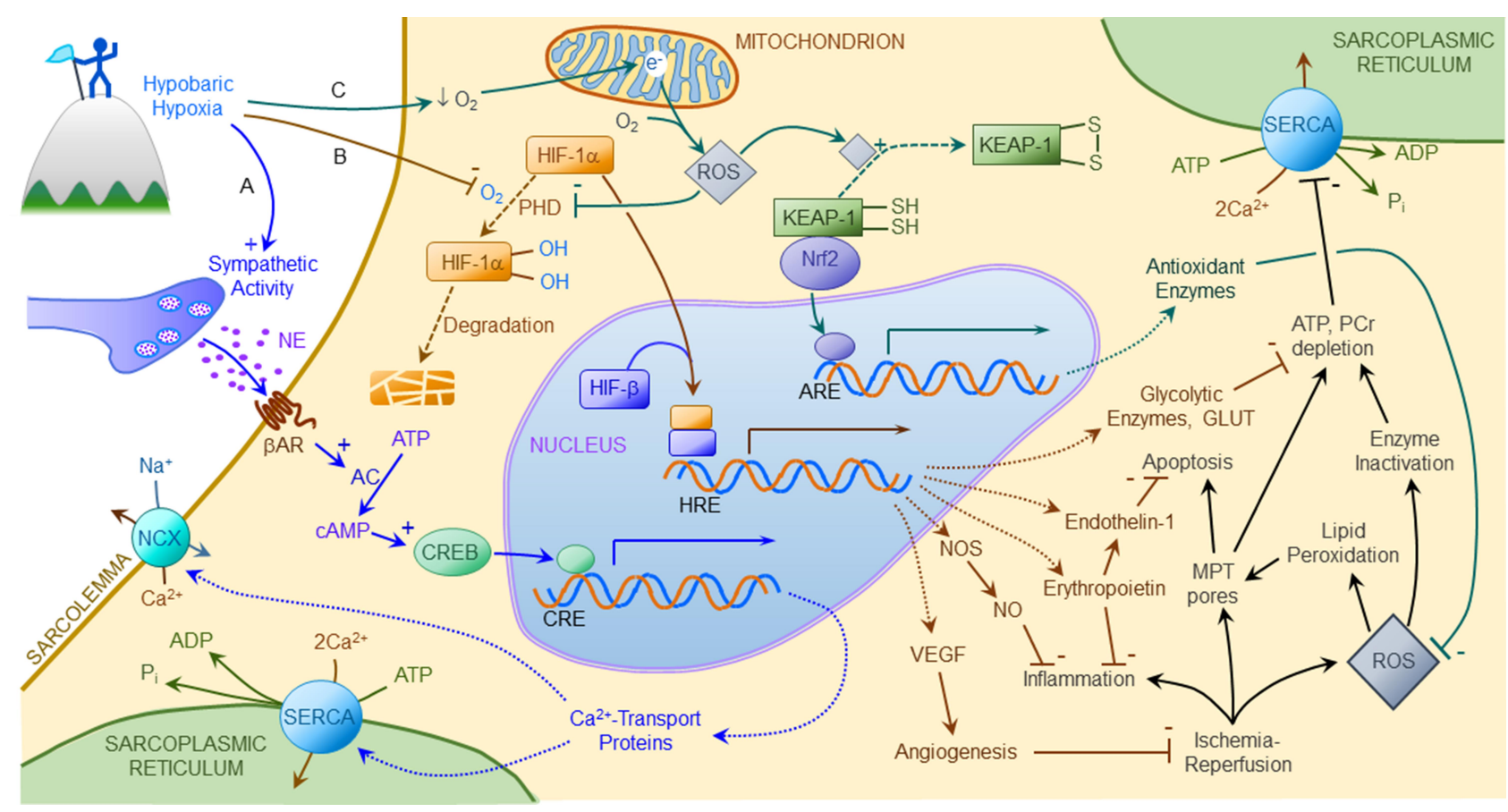

Figure 4 Hypobaric hypoxia induces cardioprotective gene expression. Hypoxia elicits cardioprotective adaptations by activating three gene programs: (A) $\beta$-adrenergic activation of cyclic nucleotide response element (CRE) binding protein (CREB) promotes transcription of genes encoding sarcoplasmic reticular Ca ${ }^{2+}$ ATPase (SERCA) and sarcolemmal $\mathrm{Na}^{+} / \mathrm{Ca}^{2+}$ exchanger (NCX), thereby improving $\mathrm{Ca}^{2+}$ homeostasis in the face of ischemia-reperfusion. (B) Intracellular hypoxia attenuates $\mathrm{O}_{2}$-dependent, prolyl hydroxylase (PHD) mediated degradation of the $\alpha$ subunit of hypoxia-inducible factor-I (HIF-I), which translocates to the nucleus, binds HIF's $\beta$ subunit, and activates hypoxia-response elements (HRE) promoting expression of genes encoding hypoxia-adaptive proteins including erythropoietin, vascular endothelial growth factor (VEGF), nitric oxide (NO) synthase (NOS), endothelin-I, glucose transporters (GLUT) and glycolytic enzymes. Erythropoietin and NO suppress inflammation, VEGF promotes coronary collateral formation, endothelin-I suppresses apoptosis, and GLUT and glycolytic enzymes support anaerobic ATP and phosphocreatine (PCr) production during ischemia. (C) Cellular hypoxia causes electron (e $\mathrm{e}^{-}$) accumulation in the mitochondrial respiratory complexes. These electrons combine with residual $\mathrm{O}_{2}$ forming reactive oxygen species (ROS) which oxidize sulfhydryl moieties in Keapl, allowing Nrf2 to activate antioxidant response elements (ARE) in genes encoding antioxidant enzymes, thereby bolstering cellular defenses against ROS overproduction. ROS also augment HIF-I-activated gene expression by blunting HIF-I $\alpha$ degradation. Collectively, these mechanisms increase cardiomyocyte resistance to ischemia-reperfusion induced $\mathrm{Ca}^{2+}$ overload, inflammation, mitochondrial permeability transition (MPT), ATP depletion and oxidative stress.

Abbreviations: AC, adenylyl cyclase; $\beta$-AR, $\beta$-adrenergic receptor; $\mathrm{AMP}$, cyclic AMP; $\mathrm{P}_{\mathrm{i}}$, inorganic phosphate. 
products malondialdehyde and oxidized protein sulfhydryls increased, ${ }^{166}$ and serum [glutathione]/[glutathione disulfide] concentration ratio, a measure of antioxidant capacity, fell. In a recent study in lowlanders spending two weeks at c $3300 \mathrm{~m}$, serum concentrations of total ROS, protein carbonyls and lipid peroxides rose by $38 \%$, $140 \%$ and $44 \%$, respectively, while antioxidant capacity fell by $17 \%$ and serum pro-inflammatory cytokines tripled. ${ }^{167}$

Although intense ROS formation injures cardiomyocytes, moderate ROS formation during controlled hypoxia in rodents activates expression of antioxidant and antiinflammatory genes, increasing cardiomyocyte resistance to ischemia. Research in hypoxia-conditioned rodents revealed robust antioxidant adaptations that paralleled ischemic tolerance. Jain et al exposed rats to extreme hypobaric hypoxia ( $9750 \mathrm{~m}$ simulated altitude; $\mathrm{P}_{\mathrm{I}} \mathrm{O}_{2}$ c $57 \mathrm{mmHg}$ ) then grouped the animals according to their hypoxia endurance. ${ }^{168}$ The myocardium of the most hypoxia-tolerant rats had greater activities of EPO, GLUT-1 and the antioxidant enzymes catalase, superoxide dismutase and heme oxygenase-1 vs myocardium of the least tolerant animals. Also in rats, two days hypobaric hypoxia $\left(7620 \mathrm{~m}\right.$ simulated altitude; $\mathrm{P}_{\mathrm{I}} \mathrm{O}_{2}$ c $78 \mathrm{mmHg}$ ) induced myocardial lipid peroxidation and protein oxidation and depleted glutathione, but by 5 days, myocardial activities of antioxidant enzymes superoxide dismutase, glutathione S-transferase, glutathione peroxidase, heme oxygenase- 1 and metallothionein all increased vs control myocardium. ${ }^{169}$ Similarly, a program of 4 cycles of 4-days hypobaric hypoxia (4600 m simulated altitude; $\mathrm{P}_{\mathrm{I}} \mathrm{O}_{2}$ c $90 \mathrm{mmHg}$ ) and 4-days normoxia elicited mitochondrial ROS formation and increased myocardial catalase, glutathione peroxidase and superoxide dismutase activities. ${ }^{170,171}$ Hearts isolated from the hypoxiaconditioned rats demonstrated increased left ventricular function and decreased lipid peroxidation following ischemia-reperfusion, vs hearts from normoxic rats. ${ }^{170}$ Similarly, hearts isolated from guinea-pigs completing a 28-day intermittent, hypoxia regimen $(5000 \mathrm{~m}$ simulated altitude for $6 \mathrm{~h} /$ $\mathrm{d} ; \mathrm{P}_{\mathrm{I}} \mathrm{O}_{2} \mathrm{c} 112 \mathrm{mmHg}$ ) and subjected to ischemia-reperfusion or $\mathrm{H}_{2} \mathrm{O}_{2}$ exposure showed increased superoxide dismutase and catalase activities and improved contractile function which was abolished by the catalase inhibitor aminotriazole. ${ }^{172}$

Exposure of mice to $10 \mathrm{~h}$ hypobaric $(4572 \mathrm{~m})$ hypoxia $\left(\mathrm{P}_{\mathrm{I}} \mathrm{O}_{2}=118 \mathrm{mmHg}\right)$ activated myocardial expression of genes encoding antioxidant enzymes catalase, glutathione peroxidase, metallothionein and microsomal glutathione
S-transferase. ${ }^{173}$ The $50 \%$ decrease in myocardial glutathione content following hypoxia indicated significant oxidative stress, which likely activated antioxidant gene expression. In dogs completing a 20-day program of cyclic, normobaric hypoxia-reoxygenation $24 \mathrm{~h}$ before occlusion-reperfusion of the left anterior descending coronary artery, infarct size was decreased by over $95 \%$ and postischemic ventricular tachyarrhythmias were sharply attenuated vs sham-conditioned dogs. ${ }^{174}$ Oral intake of antioxidant $\mathrm{N}$-acetylcysteine $2 \mathrm{~h}$ before each hypoxia session abrogated the cardioprotection, implicating ROS in the cardioprotective mechanism. Although the dogs were conditioned by intermittent, not chronic, hypoxia, these results are concordant with cardioprotection by ROS signaling in chronic hypoxia, too.

Although the molecular mediators of ROS-induced gene expression are not yet established, the ROSresponsive transcription factor nuclear factor erythroid 2-related factor 2 ( Nrf2) is the most likely candidate. ROS disrupt the disulfide bonds linking Nrf2 to its repressor, Keap-1, thereby allowing Nrf2 migration from cytosol to nucleus, where its interactions with antioxidant response elements in the promoter regions activate genes encoding a host of antioxidant and anti-inflammatory proteins ${ }^{175}$ including catalase, metallothionein, heme oxygenase-1, glutathione peroxidase, glutathione S-transferase and other elements of the cardiomyocyte's antioxidant armamentarium. ${ }^{176}$ The effects of chronic, hypobaric hypoxia on Nrf2 are as yet unknown, and merit investigation.

\section{Hypoxia-Inducible Gene Products}

When exposed to chronic hypoxia, cardiomyocytes synthesize proteins that increase their tolerance to reduced $\mathrm{O}_{2}$ availability. These proteins are products of an extensive gene expression program regulated by hypoxia-inducible factors (HIFs), the best-studied of which is HIF-1, a heterodimer of $\mathrm{O}_{2}$-regulated $\alpha$ and constitutive $\beta$ subunits. During normoxia, prolyl and arginyl hydroxylases hydroxylate HIF-1 $\alpha$, targeting it for proteasomal degradation which limits HIF-1-activated gene expression. ${ }^{177} \mathrm{HIF}-$ $1 \alpha$ hydroxylation declines as cellular $\mathrm{O}_{2}$ concentration falls, whereupon the subunit translocates to the nucleus and combines with the $\beta$ subunit forming the transcriptionally active HIF-1 heterodimer. By inactivating prolyl hydroxylase, ROS stabilize HIF-1 $\alpha$ and, thereby, augment hypoxia-activation of HIF-1's gene program. ${ }^{178-180}$ HIF-1 activates hypoxia response elements in the promoters of 
over 100 genes. ${ }^{181}$ HIF-1 activates expression of [1] glucose transporters (GLUT) and the entire glycolytic enzyme sequence beyond hexokinase, thereby augmenting glucose catabolism and anaerobic ATP production; [2] vascular endothelial growth factor (VEGF) which, by activating angiogenesis, increases collateral $\mathrm{O}_{2}$ delivery to ischemic myocardium; [3] nitric oxide synthase (NOS), which generates the anti-inflammatory metabolite nitric oxide, [4] endothelin-1 (ET-1), which activates anti-apoptotic signaling cascades ${ }^{182}$ and gene expression; ${ }^{183}$ and [5] erythropoietin (EPO), which activates red cell production in erythropoietic tissues, and also exerts anti-inflammatory actions in heart and brain, both of which are capable of synthesizing EPO. ${ }^{184,185}$ Hypoxia-induction of this diverse gene program ${ }^{181}$ increases survival and functional recovery of cardiomyocytes threatened by ischemia-reperfusion.

Chen et al evaluated coronary collateral density in patients with $>70 \%$ occlusion of one or more conduit coronary arteries. ${ }^{186}$ The patients with more extensive coronary collaterals had higher HIF- $1 \alpha$ contents in circulating monocytes and leukocytes. The association of greater collateral density and, therefore, myocardial oxygenation with increased HIF- $1 \alpha$ content argues that HIF$1 \alpha$ and its gene product VEGF were likely responsible for the increased collaterals.

Sojourns at high altitude elicit EPO production which initiates erythropoiesis to augment the blood's $\mathrm{O}_{2}$-carrying capacity. Accordingly, circulating EPO concentrations increased within one day of ascent in healthy adults ascending from sea level to $>3000 \mathrm{~m} \cdot{ }^{187}$ Analysis of glycosylated EPO glycoforms pinpointed the kidneys as the major source of circulating EPO in human subjects at $3454 \mathrm{~m}\left(\mathrm{P}_{\mathrm{I}} \mathrm{O}_{2}\right.$ c $\left.137 \mathrm{mmHg}\right){ }^{188}$ Whether circulating EPO of renal origin contributes to hypoxia-induced cardioprotection, or if hypobaric hypoxia elicits myocardial EPO formation ${ }^{184}$ in humans is unknown.

Sasaki et al studied rats acutely conditioned by 4 $\mathrm{h}$ normobaric hypoxia $\left(\mathrm{F}_{\mathrm{I}} \mathrm{O}_{2} \quad 0.10\right)$ and 24 $\mathrm{h}$ reoxygenation, followed by permanent coronary artery occlusion. ${ }^{189}$ Three weeks later, the hearts of the hypoxiaconditioned rats were found to have greater dobutaminerecruitable contractile reserve, which paralleled increased myocardial capillary and arteriolar density, blood flow and VEGF content vs hearts of non-hypoxic controls. In Jain et al's study, the myocardium of the most hypoxia-tolerant rats had greater activities of EPO and GLUT-1, as well as the aforementioned antioxidant enzymes, than myocardium of the least tolerant rats. ${ }^{168}$ In Singh et al's study of hypobaric hypoxia conditioned rats, ${ }^{169}$ the increased myocardial antioxidant enzymes at $5 \mathrm{~d}$ hypoxia were accompanied by increased HIF- $1 \alpha$ content and expression of HIF-1's gene program products EPO, VEGF, GLUT-1 and nitric oxide synthase (NOS). A recent study in mice conditioned by $14 \mathrm{~d}$ continuous, normobaric hypoxia $\left(\mathrm{F}_{\mathrm{I}} \mathrm{O}_{2}\right.$ 0.07) demonstrated increased myocardial expression of genes encoding VEGF, its receptor VEGF-R2, and RABEP2, a regulator of VEGF-R2 endosomal trafficking, vs normoxic mice. Myocardium of the hypoxic mice also demonstrated increased coronary collateral development and capillary density, and decreased myocardial infarct size following coronary artery occlusion. ${ }^{190}$

Hypobaric hypoxia is associated with increased circulating ET-1, as documented in healthy human subjects ascending to $3700-5000 \mathrm{~m}$ altitude. ${ }^{191,192}$ Although a well-recognized vasoconstrictor, ET-1 at moderate concentrations suppresses cardiomyocyte apoptosis ${ }^{182,183}$ by mobilizing signaling cascades that activate cytoprotective genes. ${ }^{193,194}$ Human $^{195}$ and rat ${ }^{196}$ cardiomyocytes synthesize and secrete ET-1 in response to hypoxia. HIF-1 activates cardiac ET-1 gene expression both directly ${ }^{197,198}$ and via EPO. ${ }^{199}$ Unlike moderate hypoxia, severe, deleterious hypoxia provokes ET-1 overproduction which activates cardiomyocyte apoptosis in a manner blunted by endothelin receptor antagonists ${ }^{200}$ and likely contributes to the hypertensive response to severe hypoxia. ${ }^{121}$

\section{Sympathetic Activity and Myocardial $\mathrm{Ca}^{2+}$ Management}

Ascent to altitude elicits sympathetic activation of the heart. ${ }^{60}$ Power spectral analysis of heart rate revealed increased sympathetic and decreased parasympathetic activities in lowlanders during 6-month sojourns at $4500-4800 \mathrm{~m}$ altitude. ${ }^{201}$ Acute exposure of male lowlanders to $4000 \mathrm{~m}$ simulated altitude in a barochamber increased serum catecholamine concentrations. ${ }^{202}$ Male lowlanders ascending to $>3500 \mathrm{~m}$ showed persistently elevated sympathetic tone and serum catecholamines. ${ }^{203}$

During hypoxia, $\beta$-adrenergic activation increases heart rate and stroke volume to increase cardiac output, thereby maintaining blood pressure and $\mathrm{O}_{2}$ delivery to the periphery. Cardiomyocytes isolated from rats completing an intermittent, hypobaric hypoxia program showed increased sarcoplasmic reticular $\mathrm{Ca}^{2+}$ ATPase activity and anti-apoptotic Bcl-2 content, and preserved sarcoplasmic reticular $\mathrm{Ca}^{2+}$ turnover following in vitro ischemia-reperfusion. ${ }^{204} \mathrm{In}$ 
dogs, administration of the $\beta_{1}$-adrenoceptor antagonist metoprolol during a 20-day intermittent hypoxia regimen prevented the robust reductions of coronary occlusionreperfusion-induced myocardial infarction and ventricular tachyarrhythmias. $^{205}$

Increased cardiomyocyte $\mathrm{Ca}^{2+}$ turnover mediates the inotropic and lusitropic effects of $\beta$-adrenergic activity. Acutely, phosphorylation of molecular targets by cyclic AMP- and $\mathrm{Ca}^{2+}$-calmodulin dependent protein kinases increases systolic sarcoplasmic reticular $\mathrm{Ca}^{2+}$ release to augment $\mathrm{Ca}^{2+}$ activation of the contractile machinery, and $\mathrm{Ca}^{2+}$ sequestration to effect diastolic relaxation. $\beta$ adrenergic activity induces genes encoding $\mathrm{Ca}^{2+}$ transporting proteins (Figure 4) via interaction of cyclic nucleotide response element (CRE) binding protein (CREB) with CRE motifs in gene promoters. ${ }^{206}$ Thus, hypoxia-reoxygenation of cardiomyocytes provoked CREB DNA-binding and expression of its target genes. $^{207} \beta$-Adrenergically activated CREB promotes synthesis of the mitochondrial anti-apoptotic factor, Bcl$2,{ }^{208}$ sarcoplasmic reticular $\mathrm{Ca}^{2+}$ ATPase, ${ }^{206}$ and sarcolemmal $\mathrm{Na}^{+} / \mathrm{Ca}^{2+}$ exchanger. ${ }^{209}$ Thus, $\beta$-adrenergic activation by hypoxia may elicit gene expression that preserves mitochondrial integrity and $\mathrm{Ca}^{2+}$ homeostasis under pathological conditions.

\section{Summary}

Preclinical studies have disclosed complex signaling cascades whereby hypoxia bolsters myocardial resistance to ischemia and reperfusion. $\beta$-Adrenergic activity, moderate ROS formation and intracellular hypoxia mobilize CREB, Nrf2 and HIF1 to activate their respective gene programs. The myriad products of these genes augment anaerobic ATP production and membrane $\mathrm{Ca}^{2+}$ transport, suppress apoptosis, preserve mitochondrial integrity and confer powerful antioxidant and anti-inflammatory protection to blunt ischemia-reperfusion induced myocardial injury (Figure 4). Defining the extent to which these diverse mechanisms effect cardioprotection in humans is crucial to develop interventions harnessing these mechanisms to treat and prevent ischemic heart disease.

\section{Disclosure}

The authors disclose no conflicts of interest in this work.

\section{References}

1. Cohen JE, Small C. Hypsographic demography: the distribution of human population by altitude. Proc Natl Acad Sci U S A. 1998;95 (24):14009-14014. doi:10.1073/pnas.95.24.14009
2. Burtscher M, Bachmann O, Hatzl T, et al. Cardiopulmonary and metabolic responses in healthy elderly humans during a 1-week hiking programme at high altitude. Eur J Appl Physiol. 2001;84 (5):379-386. doi:10.1007/s004210100393

3. Netzer N, Strohl K, Faulhaber M, Gatterer H, Burtscher M. Hypoxia-related altitude illnesses. $J$ Travel Med. 2013;20 (4):247-255. doi:10.1111/jtm.12017

4. Burtscher M, Gatterer H, Burtscher J, Mairbäurl H. Extreme terrestrial environments: life in thermal stress and hypoxia. a narrative review. Front Physiol. 2018;9:572. doi:10.3389/ fphys.2018.00572

5. Moore LG. Human genetic adaptation to high altitude. High Alt Med Biol. 2001;2(2):257-279. doi:10.1089/152702901750265341

6. Winslow RM, Monge C. Hypoxia, Polycythemia, and Chronic Mountain Sickness. Johns Hopkins Univ.Press; 1987.

7. Hackett PH, Roach RC. High-altitude illness. New Engl J Med. 2001;345(2):107-114. doi:10.1056/NEJM200107123450206

8. Basnyat B, Murdoch DR. High-altitude illness. Lancet. 2003;361 (9373):1967-1974. doi:10.1016/S0140-6736(03)13591-X

9. West JB. High living: lessons from extreme altitude. The 1984 J. Burns Amberson lecture. Am Rev Respir Dis. 1984;130 (5):917-923. doi:10.1164/arrd.1984.130.5.917

10. Gazal S, Espinoza JR, Austerlitz F, et al. The genetic architecture of chronic mountain sickness in peru. Front Genet. 2019;10:690. doi:10.3389/fgene.2019.00690

11. West JB. Acclimatization and tolerance to extreme altitude. J Wilderness Med. 1993;4(1):17-26. doi:10.1580/0953-9859-4.1.17

12. Finch CE, Tanzi RE. Genetics of aging. Science. 1997;278 (5337):407-411. doi:10.1126/science.278.5337.407

13. Nilsson PM. Genetic and environmental determinants of early vascular ageing (EVA). Curr Vasc Pharmacol. 2012;10 (6):700-701. doi:10.2174/157016112803520981

14. Bunker A, Wildenhain J, Vandenbergh A, et al. Effects of air temperature on climate-sensitive mortality and morbidity outcomes in the elderly; a systematic review and meta-analysis of epidemiological evidence. EBioMedicine. 2016;6:258-268. doi:10.1016/j.ebiom.2016.02.034

15. Crawford JE, Amaru R, Song J, et al. Natural selection on genes related to cardiovascular health in high-altitude adapted andeans. $\mathrm{Am}$ J Hum Genet. 2017;101(5):752-767. doi:10.1016/j.ajhg.2017.09.023

16. Burtscher M. Effects of living at higher altitudes on mortality: a narrative review. Aging Dis. 2014;5(4):274. doi:10.14336/ AD.2014.0500274

17. Ezzati M, Horwitz ME, Thomas DS, et al. Altitude, life expectancy and mortality from ischaemic heart disease, stroke, COPD and cancers: national population-based analysis of US counties. $J$ Epidemiol Community Health. 2012;66(7):e17-e17. doi:10.1136/jech.2010.112938

18. Faeh D, Gutzwiller F, Bopp M, Group SNCS. Lower mortality from coronary heart disease and stroke at higher altitudes in Switzerland. Circulation. 2009;120(6):495. doi:10.1161/ CIRCULATIONAHA.108.819250

19. Burtscher M, Ponchia A. The risk of cardiovascular events during leisure time activities at altitude. Prog Cardiovasc Dis. 2010;52 (6):507-511. doi:10.1016/j.pcad.2010.02.008

20. Bärtsch P, Swenson ER. Clinical practice: acute high-altitude illnesses. N Engl J Med. 2013;368(24):2294-2302. doi:10.1056/ NEJMcp 1214870

21. Richalet J-P, Lhuissier FJ. Aging, tolerance to high altitude, and cardiorespiratory response to hypoxia. High Alt Med Biol. 2015;16(2):117-124. doi:10.1089/ham.2015.0030

22. Mallet RT, Manukhina EB, Ruelas SS, Caffrey JL, Downey HF. Cardioprotection by intermittent hypoxia conditioning: evidence, mechanisms, and therapeutic potential. Am J Physiol Heart Circ Physiol. 2018;315(2):H216-H232. doi:10.1152/ ajpheart.00060.2018 
23. Boscoe FP, Schymura MJ. Solar ultraviolet-B exposure and cancer incidence and mortality in the United States, 1993-2002. BMC Cancer. 2006;6:264. doi:10.1186/1471-2407-6-264

24. Burtscher M. Lower mortality rates in those living at moderate altitude. Aging (Albany NY). 2016;8(10):2603-2604. doi:10.18632/aging.101057

25. Thielke S, Slatore CG, Banks WA. Association between Alzheimer dementia mortality rate and altitude in California counties. JAMA Psychiatry. 2015;72(12):1253-1254. doi:10.1001/jamapsychiatry.2015.1852

26. Moore LG, Rohr AL, Maisenbach JK, Reeves JT. Emphysema mortality is increased in Colorado residents at high altitude. Am Rev Respir Dis. 1982;126(2):225-228.

27. Schobersberger W, Schmid P, Lechleitner M, et al. Austrian Moderate Altitude Study 2000 (AMAS 2000). The effects of moderate altitude $(1700 \mathrm{~m})$ on cardiovascular and metabolic variables in patients with metabolic syndrome. Eur $J$ Appl Physiol. 2003;88(6):506-514. doi:10.1007/s00421-002-0736-8

28. West JB. Highest inhabitants in the world. Nature. 1986;324 (6097):517. doi:10.1038/324517a0

29. Song C, Chongsuvivatwong V, Zhu Luo Bu O, Sang Zhuo Ma B, Sriplung H. Relationship between hypertension and geographic altitude: a cross-sectional survey among residents in Tibet. $J$ Int Med Res. 2020;48(2):300060520903645. doi:10.1177/ 0300060520903645

30. Mingji C, Onakpoya IJ, Perera R, Ward AM, Heneghan CJ. Relationship between altitude and the prevalence of hypertension in Tibet: a systematic review. Heart. 2015;101(13):1054-1060. doi:10.1136/heartjnl-2014-307158

31. Aryal N, Weatherall M, Bhatta YK, Mann S. Blood pressure and hypertension in adults permanently living at high altitude: a systematic review and meta-analysis. High Alt Med Biol. 2016;17(3):185-193. doi:10.1089/ham.2015.0118

32. Beall CM. Tibetan and Andean patterns of adaptation to high-altitude hypoxia. Hum Biol. 2000;72(1):201-228.

33. Narvaez-Guerra O, Herrera-Enriquez K, Medina-Lezama J, Chirinos JA. Systemic hypertension at high altitude. Hypertension. 2018;72(3):567-578. doi:10.1161/ HYPERTENSIONAHA.118.11140

34. Bilo G, Acone L, Anza-Ramírez C, et al. Office and ambulatory arterial hypertension in highlanders: HIGHCARE-ANDES Highlanders Study. Hypertension. 2020;76(6):1962-1970. doi:10.1161/HYPERTENSIONAHA.120.16010

35. Sherpa LY, Deji SH. Lipid profile and its association with risk factors for coronary heart disease in the highlanders of Lhasa, Tibet. High Alt Med Biol. 2011;12(1):57-63. doi:10.1089/ ham.2010.1050

36. Deng B, Luo T, Huang Y, Shen T, Ma J. Prevalence and determinants of hyperlipidemia in moderate altitude areas of the Yunnan-Kweichow plateau in Southwestern China. High Alt Med Biol. 2012;13(1):13-21. doi:10.1089/ham.2011.1037

37. Lopez-Pascual A, Arévalo J, Martínez JA, González-Muniesa P. Inverse association between metabolic syndrome and altitude: a cross-sectional study in an adult population of ecuador. Front Endocrinol (Lausanne). 2018;9:658. doi:10.3389/ fendo.2018.00658

38. Rühli FJ, Henneberg M, Schaer DJ, Imhof A, Schleiffenbaum B, Woitek U. Determinants of inter-individual cholesterol level variation in an unbiased young male sample. Swiss Med Wkly. 2008;138(19-20):286-291.

39. Woolcott OO, Castillo OA, Gutierrez C, Elashoff RM, Stefanovski D, Bergman RN. Inverse association between diabetes and altitude: a cross-sectional study in the adult population of the United States. Obesity (Silver Spring). 2014;22 (9):2080-2090. doi:10.1002/oby.20800
40. Okumiya K, Sakamoto R, Ishimoto Y, et al. Glucose intolerance associated with hypoxia in people living at high altitudes in the Tibetan highland. BMJ Open. 2016;6(2):e009728. doi:10.1136/ bmjopen-2015-009728

41. Woolcott OO, Gutierrez C, Castillo OA, Elashoff RM, Stefanovski D, Bergman RN. Inverse association between altitude and obesity: a prevalence study among andean and low-altitude adult individuals of Peru. Obesity (Silver Spring). 2016;24 (4):929-937. doi:10.1002/oby.21401

42. Leon-Velarde F, Maggiorini M, Reeves JT, et al. Consensus statement on chronic and subacute high altitude diseases. High Alt Med Bio. 2005;6:147-157. doi:10.1089/ham.2005.6.147

43. Villafuerte FC, Corante N. Chronic mountain sickness: clinical aspects, etiology, management, and treatment. High Alt Med Biol. 2016;17(2):61-69. doi:10.1089/ham.2016.0031

44. Virues-Ortega J, Hogan AM, Baya-Botti A, et al. Survival and mortality in older adults living at high altitude in Bolivia: a preliminary report. J Am Geriatr Soc. 2009;57(10):1955-1956. doi:10.1111/j.1532-5415.2009.02468.x

45. Burtscher M, Hefti U, Hefti-Pichler J. High-altitude illnesses: old stories and new insights into the pathophysiology, treatment and prevention. Sports Med Health Sci. doi:10.1016/j. smhs.2021.04.001

46. Mairer K, Wille M, Burtscher M. The prevalence of and risk factors for acute mountain sickness in the Eastern and Western Alps. High Alt Med Biol. 2010;11(4):343-348. doi:10.1089/ ham.2010.1039

47. Li X, Tao F, You H, Pei T, Gao Y. Factors associated with acute mountain sickness in young Chinese men on entering highland areas. Asia Pac J Public Health. 2015;27(2):NP116-31. doi:10.1177/1010539511427956

48. Richalet JP, Larmignat P, Poitrine E, Letournel M, CanouïPoitrine F. Physiological risk factors for severe high-altitude illness: a prospective cohort study. Am J Respir Crit Care Med. 2012;185(2):192-198. doi:10.1164/rccm.201108-1396OC

49. Wu TY, Ding SQ, Liu JL, et al. Who should not go high: chronic disease and work at altitude during construction of the Qinghai-Tibet railroad. High Alt Med Biol. 2007;8(2):88-107. doi:10.1089/ham.2007.1015

50. Jayaswal R, Sivadas P, Mishra SS. Health and performance of military personnel in cold climatic environment of the western Himalayas. Med J Armed Forces India. 2001;57(4):322-325. doi:10.1016/S0377-1237(01)80014-9

51. Marshall JM. Chemoreceptors and cardiovascular control in acute and chronic systemic hypoxia. Braz J Med Biol Res. 1998;31 (7):863-888. doi:10.1590/s0100-879x1998000700002

52. Burtscher M, Faulhaber M, Flatz M, Likar R, Nachbauer W. Effects of short-term acclimatization to altitude $(3200 \mathrm{~m})$ on aerobic and anaerobic exercise performance. Int $J$ Sports Med. 2006;27(8):629-635. doi:10.1055/s-2005-872823

53. Bärtsch P, Gibbs JS. Effect of altitude on the heart and the lungs. Circulation. 2007;116(19):2191-2202. doi:10.1161/ CIRCULATIONAHA.106.650796

54. Levine BD. Going high with heart disease: the effect of high altitude exposure in older individuals and patients with coronary artery disease. High Alt Med Biol. 2015;16(2):89-96. doi:10.1089/ham.2015.0043

55. Naeije R. Physiological adaptation of the cardiovascular system to high altitude. Prog Cardiovasc Dis. 2010;52(6):456-466. doi:10.1016/j.pcad.2010.03.004

56. Lenfant C, Sullivan K. Adaptation to high altitude. $N$ Engl J Med. 1971;284(23):1298-1309. doi:10.1056/NEJM197106102842305

57. Zouboules SM, Lafave HC, O'Halloran KD, et al. Renal reactivity: acid-base compensation during incremental ascent to high altitude. J Physiol. 2018;596(24):6191-6203. doi:10.1113/ JP276973 
58. Swenson ER. Carbonic anhydrase inhibitors and high altitude illnesses. Subcell Biochem. 2014;75:361-386. doi:10.1007/97894-007-7359-2_18

59. Burtscher M, Philadelphy M, Gatterer H, et al. Physiological responses in humans acutely exposed to high altitude $(3480 \mathrm{~m})$ : minute ventilation and oxygenation are predictive for the development of acute mountain sickness. High Alt Med Biol. 2019;20:192-197. doi:10.1089/ham.2018.0143

60. Levine BD, Zuckerman JH, deFilippi CR. Effect of high-altitude exposure in the elderly: the Tenth Mountain Division study. Circulation. 1997;96(4):1224-1232. doi:10.1161/01.cir.96.4.1224

61. Parati G, Bilo G, Faini A, et al. Changes in $24 \mathrm{~h}$ ambulatory blood pressure and effects of angiotensin II receptor blockade during acute and prolonged high-altitude exposure: a randomized clinical trial. Eur Heart J. 2014;35(44):3113-3122. doi:10.1093/eurheartj/ehu275

62. Lhuissier FJ, Canouï-Poitrine F, Richalet JP. Ageing and cardiorespiratory response to hypoxia. $J$ Physiol. 2012;590 (21):5461-5474. doi:10.1113/jphysiol.2012.238527

63. Horstman D, Weiskopf R, Jackson RE. Work capacity during 3-wk sojourn at $4300 \mathrm{~m}$ : effects of relative polycythemia J Appl Physiol Respir Environ Exerc Physiol. 1980;49 (2):311-318. doi:10.1152/jappl.1980.49.2.311

64. Burtscher M, Niedermeier M, Burtscher J, Pesta D, Suchy J, Strasser B. Preparation for endurance competitions at altitude: physiological, psychological, dietary and coaching aspects. a narrative review. Front Physiol. 2018;9:1504. doi:10.3389/ fphys.2018.01504

65. Burtscher M, Philadelphy M, Burtscher J, Likar R. Sex-specific differences in blood pressure responses following acute high-altitude exposure. J Travel Med. 2021. doi:10.1093/jtm/ taab035

66. Cymerman A, Reeves JT, Sutton JR, et al. Operation Everest II: maximal oxygen uptake at extreme altitude. J Appl Physiol (1985). 1989;66(5):2446-2453. doi:10.1152/jappl.1989.66.5.2446

67. Burtscher M, Nachbauer W, Baumgartl P, Philadelphy M. Benefits of training at moderate altitude versus sea level training in amateur runners. Eur J Appl Physiol Occup Physiol. 1996;74 (6):558-563. doi:10.1007/bf02376773

68. Parati G, Agostoni P, Basnyat B, et al. Clinical recommendations for high altitude exposure of individuals with pre-existing cardiovascular conditions: a joint statement by the European Society of Cardiology, the Council on Hypertension of the European Society of Cardiology, the European Society of Hypertension, the International Society of Mountain Medicine, the Italian Society of Hypertension and the Italian Society of Mountain Medicine. Eur Heart J. 2018;39(17):1546-1554. doi:10.1093/eurheartj/ehx720

69. Rimoldi SF, Sartori C, Seiler C, et al. High-altitude exposure in patients with cardiovascular disease: risk assessment and practical recommendations. Prog Cardiovasc Dis. 2010;52(6):512-524. doi:10.1016/j.pcad.2010.03.005

70. Higgins JP, Tuttle T, Higgins JA. Altitude and the heart: is going high safe for your cardiac patient? Am Heart J. 2010;159 (1):25-32. doi:10.1016/j.ahj.2009.10.028

71. Faulhaber M, Flatz M, Gatterer H, Schobersberger W, Burtscher M. Prevalence of cardiovascular diseases among alpine skiers and hikers in the Austrian Alps. High Alt Med Biol. 2007;8 (3):245-252. doi:10.1089/ham.2007.1005

72. Alexander JK. Coronary heart disease at altitude. Tex Heart Inst J 1994;21(4):261-266.

73. Erdmann J, Sun KT, Masar P, Niederhauser H. Effects of exposure to altitude on men with coronary artery disease and impaired left ventricular function. Am J Cardiol. 1998;81(3):266-270. doi:10.1016/s0002-9149(97)00901-6

74. Hackett PH, Creagh CE, Grover RF, et al. High-altitude pulmonary edema in persons without the right pulmonary artery. $N$ Engl J Med. 1980;302(19):1070-1073. doi:10.1056/NEJM198005083021907
75. Richalet JP, Chenivesse C, Larmignat P, Meille L. High altitude pulmonary edema, down syndrome, and obstructive sleep apneas. High Alt Med Biol. 2008;9(2):179-181. doi:10.1089/ ham.2007.1062

76. Sartori C, Allemann Y, Trueb L, Delabays A, Nicod P, Scherrer U. Augmented vasoreactivity in adult life associated with perinatal vascular insult. Lancet. 1999;353 (9171):2205-2207. doi:10.1016/S0140-6736(98)08352-4

77. Lichtblau M, Saxer S, Latshang TD, et al. Altitude travel in patients with pulmonary hypertension: randomized pilot-trial evaluating nocturnal oxygen therapy. Front Med (Lausanne). 2020;7:502. doi:10.3389/fmed.2020.00502

78. Allemann Y, Hutter D, Lipp E, et al. Patent foramen ovale and high-altitude pulmonary edema. JAMA. 2006;296(24):2954-2958. doi:10.1001/jama.296.24.2954

79. Scherrer U, Allemann Y, Jayet PY, Rexhaj E, Sartori C. High altitude, a natural research laboratory for the study of cardiovascular physiology and pathophysiology. Prog Cardiovasc Dis. 2010;52(6):451-455. doi:10.1016/j.pcad.2010. 02.002

80. Harinck E, Hutter PA, Hoorntje TM, et al. Air travel and adults with cyanotic congenital heart disease. Circulation. 1996;93 (2):272-276. doi:10.1161/01.cir.93.2.272

81. Alexander JK. Coronary problems associated with altitude and air travel. Cardiol Clin. 1995;13(2):271-278.

82. Donegani E, Hillebrandt D, Windsor J, et al. Pre-existing cardiovascular conditions and high altitude travel. Consensus statement of the Medical Commission of the Union Internationale des Associations d'Alpinisme (UIAA MedCom) Travel Medicine and Infectious Disease. Travel Med Infect Dis. 2014;12(3):237-252. doi:10.1016/j. tmaid.2014.02.004

83. Schmid JP, Noveanu M, Gaillet R, Hellige G, Wahl A, Saner H. Safety and exercise tolerance of acute high altitude exposure $(3454 \mathrm{~m})$ among patients with coronary artery disease. Heart. 2006;92(7):921-925. doi:10.1136/hrt.2005.072520

84. Agostoni P, Cattadori G, Guazzi M, et al. Effects of simulated altitude-induced hypoxia on exercise capacity in patients with chronic heart failure. Am J Med. 2000;109(6):450-455. doi:10.1016/s0002-9343(00)00532-5

85. Agostoni P. Considerations on safety and treatment of patients with chronic heart failure at high altitude. High Alt Med Biol. 2013;14(2):96-100. doi:10.1089/ham.2012.1117

86. Savonitto S, Cardellino G, Doveri G, et al. Effects of acute exposure to altitude $(3460 \mathrm{~m})$ on blood pressure response to dynamic and isometric exercise in men with systemic hypertension. Am J Cardiol. 1992;70(18):1493-1497. doi:10.1016/0002-9149(92)90308-1

87. Winkler L, Lhuissier FJ, Richalet JP. Systemic blood pressure at exercise in hypoxia in hypertensive and normotensive patients. J Hypertens. 2017;35(12):2402-2410. doi:10.1097/ НJH.0000000000001479

88. Lyamina NP, Lyamina SV, Senchiknin VN, Mallet RT, Downey HF, Manukhina EB. Normobaric hypoxia conditioning reduces blood pressure and normalizes nitric oxide synthesis in patients with arterial hypertension. $J$ Hypertens. 2011;29 (11):2265-2272. doi:10.1097/HJH.0b013e32834b5846

89. Keyes LE, Sallade TD, Duke C, et al. Blood pressure and altitude: an observational cohort study of hypertensive and nonhypertensive himalayan trekkers in Nepal. High Alt Med Biol. 2017;18 (3):267-277. doi:10.1089/ham.2017.0001

90. Kivipelto M, Ngandu T, Fratiglioni L, et al. Obesity and vascular risk factors at midlife and the risk of dementia and Alzheimer disease. Arch Neurol. 2005;62(10):1556-1560. doi:10.1001/ archneur.62.10.1556 
91. Broce IJ, Tan CH, Fan CC, et al. Dissecting the genetic relationship between cardiovascular risk factors and Alzheimer's disease. Acta Neuropathol. 2019;137(2):209-226. doi:10.1007/s00401018-1928-6

92. Whitmer RA, Sidney S, Selby J, Johnston SC, Yaffe K. Midlife cardiovascular risk factors and risk of dementia in late life. Neurology. 2005;64(2):277-281. doi:10.1212/01.WNL.000014 9519.47454.F2

93. Rabin JS, Schultz AP, Hedden T, et al. Interactive associations of vascular risk and $\beta$-amyloid burden with cognitive decline in clinically normal elderly individuals: findings from the Harvard Aging Brain Study. JAMA Neurol. 2018;75(9):1124-1131. doi:10.1001/jamaneurol.2018.1123

94. Fiuza-Luces C, Santos-Lozano A, Joyner M, et al. Exercise benefits in cardiovascular disease: beyond attenuation of traditional risk factors. Nat Rev Cardiol. 2018;15(12):731-743. doi:10.1038/s41569-018-0065-1

95. Toth P, Tarantini S, Csiszar A, Ungvari Z. Functional vascular contributions to cognitive impairment and dementia: mechanisms and consequences of cerebral autoregulatory dysfunction, endothelial impairment, and neurovascular uncoupling in aging. Am J Physiol Heart Circ Physiol. 2017;312(1):H1-h20. doi:10.1152/ajpheart.00581.2016

96. Asmaro D, Mayall J, Ferguson S. Cognition at altitude: impairment in executive and memory processes under hypoxic conditions. Aviat Space Environ Med. 2013;84(11):1159-1165. doi:10.3357/asem.3661.2013

97. Bonnon M, Noël-Jorand MC, Therme P. Psychological changes during altitude hypoxia. Aviat Space Environ Med. 1995;66 (4):330-335

98. Griva K, Stygall J, Wilson MH, et al. Caudwell Xtreme Everest: a prospective study of the effects of environmental hypoxia on cognitive functioning. PLoS One. 2017;12(3):e0174277. doi:10.1371/journal.pone.0174277

99. Nation DA, Bondi MW, Gayles E, Delis DC. Mechanisms of memory dysfunction during high altitude hypoxia training in military aircrew. J Int Neuropsychol Soc. 2017;23(1):1-10. doi:10.1017/s1355617716000965

100. Pagani M, Ravagnan G, Salmaso D. Effect of acclimatisation to altitude on learning. Cortex. 1998;34(2):243-251. doi:10.1016/ S0010-9452(08)70751-2

101. Pelamatti G, Pascotto M, Semenza C. Verbal free recall in high altitude: proper names vs common names. Cortex. 2003;39 (1):97-103. doi:10.1016/S0010-9452(08)70077-7

102. Nelson M. Psychological testing at high altitudes. Aviat Space Environ Med. 1982;53:122-126.

103. de Aquino Lemos V, Antunes HK, Dos Santos RV, Lira FS, Tufik S, de Mello MT. High altitude exposure impairs sleep patterns, mood, and cognitive functions. Psychophysiology. 2012;49(9):1298-1306. doi:10.1111/j.1469-8986.2012.01411.x

104. Wilson $\mathrm{MH}$, Newman S, Imray $\mathrm{CH}$. The cerebral effects of ascent to high altitudes. Lancet Neurol. 2009;8(2):175-191. doi:10.1016/ S1474-4422(09)70014-6

105. Hur T. Parkinsonism after climbing high amplitude mountain: a case report. J Neurol Sci. 2015;357:e270. doi:10.1016/j. jns.2015.08.948

106. Swaminath PV, Ragothaman M, Muthane UB, Udupa SA, Rao SL, Govindappa SS. Parkinsonism and personality changes following an acute hypoxic insult during mountaineering. Movement Disorders. 2006;21(8):1296-1297. doi:10.1002/ mds.20941

107. Park K, Yang KI. Delayed parkinsonism following high mountain climbing: a case report. Neurology Asia. 2013;18(1):99-101.

108. Litch JA, Bishop RA. High-altitude global amnesia. Wilderness Environ Med. 2000;11(1):25-28. doi:10.1580/1080-6032(2000) 011[0025:haga]2.3.co;2
109. Imray $\mathrm{CH}$, Myers SD, Pattinson KT, et al. Effect of exercise on cerebral perfusion in humans at high altitude. J Appl Physiol (1985). 2005;99(2):699-706. doi:10.1152/japplphysiol. 00973.2004

110. Sanborn MR, Edsell ME, Kim MN, et al. Cerebral hemodynamics at altitude: effects of hyperventilation and acclimatization on cerebral blood flow and oxygenation. Wilderness Environ Med. 2015;26(2):133-141. doi:10.1016/j.wem.2014.10.001

111. Lee P, Chandel NS, Simon MC. Cellular adaptation to hypoxia through hypoxia inducible factors and beyond. Nat Rev Mol Cell Biol. 2020;21:1-16. doi:10.1038/s41580-019-0188-1

112. Semenza GL. Regulation of mammalian O2 homeostasis by hypoxia-inducible factor 1. Annu Rev Cell Dev Biol. 1999;15 (1):551-578. doi:10.1146/annurev.cellbio.15.1.551

113. Leonard MO, Kieran NE, Howell K, et al. Reoxygenation-specific activation of the antioxidant transcription factor Nrf2 mediates cytoprotective gene expression in ischemia-reperfusion injury. FASEB J. 2006;20(14):2624-2626. doi:10.1096/fj.06-5097fje

114. Lendahl U, Lee KL, Yang H, Poellinger L. Generating specificity and diversity in the transcriptional response to hypoxia. Nat Rev Genet. 2009;10(12):821-832. doi:10.1038/nrg2665

115. Mela L, Goodwin CW, Miller LD. In vivo control of mitochondrial enzyme concentrations and activity by oxygen. $A m$ $J \quad$ Physiol. 1976;231(6):1811-1816. doi:10.1152/ ajplegacy.1976.231.6.1811

116. Zhuang J-G, Zhou Z-N. Protective effects of intermittent hypoxic adaptation on myocardium and its mechanisms. Neurosignals. 1999;8(4-5):316-322. doi:10.1159/000014602

117. Almohanna AM, Wray S. Hypoxic conditioning in blood vessels and smooth muscle tissues: effects on function, mechanisms, and unknowns. Am J Physiol Heart Circulatory Physiol. 2018;315(4): H756-H770. doi:10.1152/ajpheart.00725.2017

118. Bernaudin M, Nedelec A-S, Divoux D, MacKenzie ET, Petit E, Schumann-Bard P. Normobaric hypoxia induces tolerance to focal permanent cerebral ischemia in association with an increased expression of hypoxia-inducible factor-1 and its target genes, erythropoietin and VEGF, in the adult mouse brain. J Cerebral Blood Flow Metab. 2002;22(4):393-403. doi:10.1097/00004647200204000-00003

119. Burtscher J, Maglione V, Di Pardo A, Millet GP, Schwarzer C, Zangrandi LA. Rationale for hypoxic and chemical conditioning in huntington's disease. Int J Mol Sci. 2021;22:582. doi:10.3390/ ijms22020582

120. Teppema LJ, Dahan A. The ventilatory response to hypoxia in mammals: mechanisms, measurement, and analysis. Physiol Rev. 2010;90(2):675-754. doi:10.1152/physrev.00012.2009

121. Serebrovskaya TV, Manukhina EB, Smith ML, Downey HF, Mallet RT. Intermittent hypoxia: cause of or therapy for systemic hypertension? Exp Biol Med. 2008;233(6):627-650. doi:10.3181/ 0710-MR-267

122. Guillemin K, Krasnow MA. The hypoxic response: huffing and HIFing. Cell. 1997;89(1):9-12. doi:10.1016/S0092-8674(00) 80176-2

123. Lourenço CF, Ledo A, Barbosa RM, Laranjinha J. Neurovascularneuroenergetic coupling axis in the brain: master regulation by nitric oxide and consequences in aging and neurodegeneration. Free Radic Biol Med. 2017;108:668-682. doi:10.1016/j. freeradbiomed.2017.04.026

124. Feddersen B, Neupane P, Thanbichler F, et al. Regional differences in the cerebral blood flow velocity response to hypobaric hypoxia at high altitudes. J Cereb Blood Flow Metab. 2015;35 (11):1846-1851. doi:10.1038/jcbfm.2015.142

125. LaManna JC, Vendel LM, Farrell RM. Brain adaptation to chronic hypobaric hypoxia in rats. J Appl Physiol. 1992;72 (6):2238-2243. doi:10.1152/jappl.1992.72.6.2238 
126. LaManna JC, Chavez JC, Pichiule P. Structural and functional adaptation to hypoxia in the rat brain. J Exp Biol. 2004;207(Pt 18):3163-3169. doi:10.1242/jeb.00976

127. Boero JA, Ascher J, Arregui A, Rovainen C, Woolsey TA. Increased brain capillaries in chronic hypoxia. $J$ Appl Physiol. 1999;86(4):1211-1219. doi:10.1152/jappl.1999.86.4.1211

128. De Strooper B, Karran E. The cellular phase of Alzheimer's disease. Cell. 2016;164(4):603-615. doi:10.1016/j. cell.2015.12.056

129. Navarrete-Opazo A, Mitchell GS. Therapeutic potential of intermittent hypoxia: a matter of dose. Am J Physiol Regul Integr Comp Physiol. 2014;307(10):R1181-R1197. doi:10.1152/ ajpregu.00208.2014

130. Liu X, Xu D, Hall JR, et al. Enhanced cerebral perfusion during brief exposures to cyclic intermittent hypoxemia. J Appl Physiol (1985). 2017;123(6):1689-1697. doi:10.1152/japplphysiol.00647.2017

131. Iwamoto E, Hanson BE, Bock JM, Casey DP. Intermittent hypoxia enhances shear-mediated dilation of the internal carotid artery in young adults. J Appl Physiol. 2020;129(3):603-611. doi:10.1152/japplphysiol.00274.2020

132. Kalaria RN, Spoors L, Laude EA, et al. Hypoxia of sleep apnoea: cardiopulmonary and cerebral changes after intermittent hypoxia in rats. Respir Physiol Neurobiol. 2004;140(1):53-62. doi:10.1016/j.resp.2004.01.003

133. Chávez JC, Agani F, Pichiule P, LaManna JC. Expression of hypoxia-inducible factor-1alpha in the brain of rats during chronic hypoxia. J Appl Physiol (1985). 2000;89(5):1937-1942. doi:10.1152/jappl.2000.89.5.1937

134. Bayer U, Likar R, Pinter G, et al. Intermittent hypoxic-hyperoxic training on cognitive performance in geriatric patients. Alzheimer's \& Dementia. 2017;3(1):114-122.

135. Schega L, Peter B, Törpel A, Mutschler H, Isermann B, Hamacher D. Effects of intermittent hypoxia on cognitive performance and quality of life in elderly adults: a pilot study. Gerontology. 2013;59(4):316-323. doi:10.1159/000350927

136. Schega L, Peter B, Brigadski T, et al. Effect of intermittent normobaric hypoxia on aerobic capacity and cognitive function in older people. J Sci Med Sport. 2016;19(11):941-945. doi:10.1016/j.jsams.2016.02.012

137. Serebrovska ZO, Serebrovska TV, Kholin VA, et al. Intermittent hypoxia-hyperoxia training improves cognitive function and decreases circulating biomarkers of alzheimer's disease in patients with mild cognitive impairment: a Pilot Study. Int J Mol Sci. 2019;20(21):5405. doi:10.3390/ijms20215405

138. Wang $H$, Shi $X$, Schenck $H$, et al. Intermittent hypoxia training for treating mild cognitive impairment: a Pilot Study. Am J Alzheimers Dis Other Demen. 2020;35:1533317519896725. doi:10.1177/1533317519896725

139. Baillieul S, Chacaroun S, Doutreleau S, Detante O, Pépin JL, Verges S. Hypoxic conditioning and the central nervous system: a new therapeutic opportunity for brain and spinal cord injuries? Exp Biol Med. 2017;242(11):1198-1206. doi:10.1177/ 1535370217712691

140. Manukhina EB, Downey HF, Shi X, Mallet RT. Intermittent hypoxia training protects cerebrovascular function in Alzheimer's disease. Exp Biol Med (Maywood). 2016;241 (12):1351-1363. doi:10.1177/1535370216649060

141. Manukhina EB, Goryacheva AV, Barskov IV, et al. Prevention of neurodegenerative damage to the brain in rats in experimental Alzheimer's disease by adaptation to hypoxia. Neurosci Behav Physiol. 2010;40(7):737-743. doi:10.1007/s11055-010-9320-6

142. Correia SC, Machado NJ, Alves MG, Oliveira PF, Moreira PI. Intermittent hypoxic conditioning rescues cognition and mitochondrial bioenergetic profile in the triple transgenic mouse model of Alzheimer's Disease. Int J Mol Sci. 2021;22(1):461. doi:10.3390/ijms22010461
143. Belikova MV, Kolesnikova EE, Serebrovskaya TV. Intermittent hypoxia and experimental Parkinson's disease. Intermittent Hypoxia Human Dis. 2012;147-153.

144. Ma H, Zhang D, Li X, Ma H, Wang N, Wang Y. Long-term exposure to high altitude attenuates verbal and spatial working memory: evidence from an event-related potential study. Brain Behav. 2019;9(4):e01256. doi:10.1002/brb3.1256

145. Hill CM, Dimitriou D, Baya A, et al. Cognitive performance in high-altitude Andean residents compared with low-altitude populations: from childhood to older age. Neuropsychology. 2014;28 (5):752. doi:10.1037/neu0000065

146. Richardson C, Hogan AM, Bucks RS, et al. Neurophysiological evidence for cognitive and brain functional adaptation in adolescents living at high altitude. Clin Neurophysiol. 2011;122(9):1726-1734. doi:10.1016/j. clinph.2011.02.001

147. Calbet JA, Boushel R, Radegran G, Sondergaard H, Wagner PD, Saltin B. Determinants of maximal oxygen uptake in severe acute hypoxia. Am J Physiol Regul Integr Comp Physiol. 2003;284(2): R291-303. doi:10.1152/ajpregu.00155.2002

148. Wehrlin JP, Hallen J. Linear decrease in.VO2max and performance with increasing altitude in endurance athletes. Eur J Appl Physiol Occup Physiol. 2006;96(4):404-412. doi:10.1007/ s00421-005-0081-9

149. Saugy JJ, Rupp T, Faiss R, Lamon A, Bourdillon N, Millet GP. Cycling time trial is more altered in hypobaric than normobaric hypoxia. Med Sci Sports Exerc. 2016;48(4):680-688. doi:10.1249/MSS.0000000000000810

150. Richalet JP. CrossTalk opposing view: barometric pressure, independent of $\mathrm{P} O \mathrm{O} 2$, is not the forgotten parameter in altitude physiology and mountain medicine. $J$ Physiol. 2020;598 (5):897-899. doi:10.1113/JP279160

151. Millet GP, Debevec T. CrossTalk proposal: barometric pressure, independent of $\mathrm{P} \mathrm{O} 2$, is the forgotten parameter in altitude physiology and mountain medicine. $J$ Physiol. 2020;598 (5):893-896. doi:10.1113/JP278673

152. Richalet JP, Kacimi R, Antezana AM. The control of cardiac chronotropic function in hypobaric hypoxia. Int J Sports Med. 1992;13(Suppl 1):S22-4. doi:10.1055/s-2007-1024582

153. Mourot L. Limitation of Maximal Heart Rate in Hypoxia: mechanisms and Clinical Importance. Front Physiol. 2018;9:972. doi:10.3389/fphys.2018.00972

154. Fukuda T, Maegawa T, Matsumoto A, et al. Effects of acute hypoxia at moderate altitude on stroke volume and cardiac output during exercise. Int Heart J. 2010;51(3):170-175. doi:10.1536/ihj.51.170

155. Gore CJ, Hahn AG, Scroop GC, et al. Increased arterial desaturation in trained cyclists during maximal exercise at $580 \mathrm{~m}$ altitude. Research Support, Non-U.S. Gov't. J Appl Physiol. 1996;80 (6):2204-2210. doi:10.1152/jappl.1996.80.6.2204

156. Mourot L, Millet GP. Is maximal heart rate decrease similar between normobaric versus hypobaric hypoxia in trained and untrained subjects? High Alt Med Biol. 2019;20(1):94-98. doi:10.1089/ham.2018.0104

157. Casillas JM, Gudjoncik A, Gremeaux V, Aulagne J, Besson D, Laroche D. Assessment tools for personalizing training intensity during cardiac rehabilitation: literature review and practical proposals. Ann Phys Rehabil Med. 2017;60(1):43-49. doi:10.1016/j.rehab.2016.01.011

158. Netzer NC, Chytra R, Kupper T. Low intense physical exercise in normobaric hypoxia leads to more weight loss in obese people than low intense physical exercise in normobaric sham hypoxia. Sleep Breathing. 2008;12(2):129-134. doi:10.1007/s11325-007-0149-3

159. Kong Z, Zang Y, Hu Y. Normobaric hypoxia training causes more weight loss than normoxia training after a 4-week residential camp for obese young adults. Sleep Breathing. 2014;18 (3):591-597. doi:10.1007/s11325-013-0922-4 
160. Casey DP, Joyner MJ. Compensatory vasodilatation during hypoxic exercise: mechanisms responsible for matching oxygen supply to demand. $J$ Physiol. 2012;590(24):6321-6326. doi:10.1113/jphysiol.2012.242396

161. Casey DP, Madery BD, Curry TB, Eisenach JH, Wilkins BW, Joyner MJ. Nitric oxide contributes to the augmented vasodilatation during hypoxic exercise. J Physiol. 2010;588(Pt 2):373-385. doi:10.1113/jphysiol.2009.180489

162. Casey DP, Curry TB, Wilkins BW, Joyner MJ. Nitric oxide-mediated vasodilation becomes independent of beta-adrenergic receptor activation with increased intensity of hypoxic exercise. J Appl Physiol (1985). 2011;110(3):687-694. doi:10.1152/japplphysiol.00787.2010

163. Montero D, Lundby C. Effects of exercise training in hypoxia versus normoxia on vascular health. Sports Med. 2016;46 (11):1725-1736. doi:10.1007/s40279-016-0570-5

164. Kleinnibbelink G, Stens NA, Fornasiero A, et al. The acute and chronic effects of high-intensity exercise in hypoxia on blood pressure and post-exercise hypotension: a randomized cross-over trial. Medicine (Baltimore). 2020;99(39):e22411. doi:10.1097/ MD.0000000000022411

165. Jefferson JA, Simoni J, Escudero E, et al. Increased oxidative stress following acute and chronic high altitude exposure. High Alt Med Biol. 2004;5(1):61-69. doi:10.1089/ 152702904322963690

166. Magalhães J, Ascensão A, Viscor G, et al. Oxidative stress in humans during and after 4 hours of hypoxia at a simulated altitude of 5500 m. Aviat Space Environ Med. 2004;75(1):16-22.

167. Mrakic-Sposta S, Gussoni M, Dellanoce C, et al. Effects of acute and sub-acute hypobaric hypoxia on oxidative stress: a field study in the Alps. Eur J Appl Physiol. 2021;121(1):297-306. doi:10.1007/s00421-020-04527-x

168. Jain K, Suryakumar G, Prasad R, Ganju L. Upregulation of cytoprotective defense mechanisms and hypoxia-responsive proteins imparts tolerance to acute hypobaric hypoxia. High Alt Med Biol. 2013;14(1):65-77. doi:10.1089/ham.2012.1064

169. Singh M, Thomas P, Shukla D, Tulsawani R, Saxena S, Bansal A. Effect of subchronic hypobaric hypoxia on oxidative stress in rat heart. Appl Biochem Biotechnol. 2013;169(8):2405-2419. doi:10.1007/s12010-013-0141-2

170. Herrera EA, Farías JG, González-Candia A, Short SE, CarrascoPozo C, Castillo RL. $\Omega 3$ Supplementation and intermittent hypobaric hypoxia induce cardioprotection enhancing antioxidant mechanisms in adult rats. Mar Drugs. 2015;13(2):838-860. doi: $10.3390 / \mathrm{md} 13020838$

171. Aguilar M, González-Candia A, Rodríguez J, et al. Mechanisms of cardiovascular protection associated with intermittent hypobaric hypoxia exposure in a rat model: role of oxidative stress. Int J Mol Sci. 2018;19:366. doi:10.3390/ijms19020366

172. Guo HC, Zhang Z, Zhang LN, et al. Chronic intermittent hypobaric hypoxia protects the heart against ischemia/reperfusion injury through upregulation of antioxidant enzymes in adult guinea pigs. Acta Pharmacol Sin. 2009;30(7):947-955. doi:10.1038/ aps.2009.57

173. Karar J, Dolt KS, Mishra MK, Arif E, Javed S, Pasha MA. Expression and functional activity of pro-oxidants and antioxidants in murine heart exposed to acute hypobaric hypoxia. FEBS Lett. 2007;581(24):4577-4582. doi:10.1016/j.febslet.2007.08.044

174. Estrada JA, Williams AG, Sun J, et al. $\delta$-Opioid receptor (DOR) signaling and reactive oxygen species (ROS) mediate intermittent hypoxia induced protection of canine myocardium. Basic Res Cardiol. 2016;111(2):17. doi:10.1007/s00395-016-0538-5

175. He F, Ru X, Wen T. NRF2, a Transcription Factor for Stress Response and Beyond. Int J Mol Sci. 2020;21. doi:10.3390/ ijms21134777.
176. Shanmugam G, Narasimhan M, Conley RL, et al. Chronic endurance exercise impairs cardiac structure and function in middle-aged mice with impaired Nrf2 Signaling. Front Physiol. 2017;8:268. doi:10.3389/fphys.2017.00268

177. Stockmann C, Fandrey J. Hypoxia-induced erythropoietin production: a paradigm for oxygen-regulated gene expression. Clin Exp Pharmacol Physiol. 2006;33(10):968-979. doi:10.1111/ j.1440-1681.2006.04474.x

178. Belaidi E, Morand J, Gras E, Pépin JL, Godin-Ribout D. Targeting the ROS-HIF-1-endothelin axis as a therapeutic approach for the treatment of obstructive sleep apnea-related cardiovascular complications. Pharmacol Ther. 2016;168:1-11. doi:10.1016/j.pharmthera.2016.07.010

179. Huang YT, Liu CH, Yang YC, et al. ROS- and HIF1 $\alpha$-dependent $\mathrm{IGFBP}_{3}$ upregulation blocks IGF1 survival signaling and thereby mediates high-glucose-induced cardiomyocyte apoptosis. J Cell Physiol. 2019;234:13557-13570. doi:10.1002/jcp.28034

180. Jiang L, Zeng $\mathrm{H}$, Ni L, et al. HIF-1 $\alpha$ preconditioning potentiates antioxidant activity in ischemic injury: the role of sequential administration of dihydrotanshinone I and protocatechuic aldehyde in cardioprotection. Antioxid Redox Signal. 2019;31:227-242. doi:10.1089/ars.2018.7624

181. Semenza GL. Hypoxia-inducible factor 1 (HIF-1) pathway. Sci STKE. 2007;2007(407):cm8. doi:10.1126/stke.4072007cm8

182. Sugden PH. An overv iew of endothelin signaling in the cardiac myocyte. J Mol Cell Cardiol. 2003;35:871-886. doi:10.1016/ s0022-2828(03)00153-6

183. Suzuki YJ. Growth factor signaling for cardioprotection against oxidative stress-induced apoptosis. Antioxid Redox Signal. 2003;5:741-749. doi:10.1089/152308603770380043

184. Ryou MG, Flaherty DC, Hoxha B, et al. Pyruvate-fortified cardioplegia evokes myocardial erythropoietin signaling in swine undergoing cardiopulmonary bypass. Am J Physiol Heart Circ Physiol. 2009;297(5):H1914-22. doi:10.1152/ ajpheart.01213.2008

185. Ryou MG, Liu R, Ren M, Sun J, Mallet RT, Yang SH. Pyruvate protects the brain against ischemia-reperfusion injury by activating the erythropoietin signaling pathway. Stroke. 2012;43 (4):1101-1107. doi:10.1161/STROKEAHA.111.620088

186. Chen SM, Li YG, Zhang HX, et al. Hypoxia-inducible factor-1alpha induces the coronary collaterals for coronary artery disease. Coron Artery Dis. 2008;19(3):173-179. doi:10.1097/ MCA.0b013e3282fa4b2c

187. Piperno A, Galimberti S, Mariani R, et al. Modulation of hepcidin production during hypoxia-induced erythropoiesis in humans in vivo: data from the HIGHCARE project. Blood. 2011;117 (10):2953-2959. doi:10.1182/blood-2010-08-299859

188. Lundby AK, Keiser S, Siebenmann C, Schäffer L, Lundby C. Kidney-synthesized erythropoietin is the main source for the hypoxia-induced increase in plasma erythropoietin in adult humans. Eur J Appl Physiol. 2014;114(6):1107-1111. doi:10.1007/s00421-014-2844-7

189. Sasaki H, Fukuda S, Otani H, et al. Hypoxic preconditioning triggers myocardial angiogenesis: a novel approach to enhance contractile functional reserve in rat with myocardial infarction. J Mol Cell Cardiol. 2002;34(3):335-348. doi:10.1006/ jmcc. 2001.1516

190. Aghajanian A, Zhang H, Buckley BK, Wittchen ES, Ma WY, Faber JE. Decreased inspired oxygen stimulates de novo formation of coronary collaterals in adult heart. $\mathrm{J} \mathrm{Mol} \mathrm{Cell} \mathrm{Cardiol.}$ 2021;150:1-11. doi:10.1016/j.yjmcc.2020.09.015

191. Morganti A, Giussani M, Sala C, et al. Effects of exposure to high altitude on plasma endothelin-1 levels in normal subjects. $J \quad H y p e r t e n s$. 1995;13:859-865. doi:10.1097/00004872199508000-00006 
192. Zhou Q, Yang S, Luo Y, et al. A randomly-controlled study on the cardiac function at he early stage of return to the plains after short-term exposure to high altitude. PLoS One. 2012;7:e31097. doi:10.1371/journal.pone.0031097

193. Kitta K, Clément SA, Remeika J, Blumberg JB, Suzuki YJ. Endothelin-1 induces phosphorylation of GATA-4 transcription factor in the HL-1 atrial-muscle cell line. Biochem J. 2001;359:375-380. doi:10.1042/0264-6021:3590375

194. Hautala N, Tenhunen O, Szokodi I, Ruskoaho H. Direct left ventricular wall stretch activates $\mathrm{GATA}_{4}$ binding in perfused rat heart: involvement of autocrine/paracrine pathways. Pflügers Arch. 2002;443:362-369. doi:10.1007/s004240100699

195. Verma S, Rao V, Weisel RD, et al. Novel cardioprotective effects of pravastatin in human ventricular cardiomyocytes subjected to hypoxia and reoxygenation: beneficial effects of statins independent of endothelial cells. J Surg Res. 2004;119:66-71. doi:10.1016/j.jss.2003.10.011

196. Kagamu H, Suzuki T, Arakawa M, Mitsui Y. Low oxygen enhances endothelin-1 (ET-1) production and responsiveness to ET-1 in cultured cardiac myocytes. Biochem Biophys Res Commun. 1994;202:1612-1618. doi:10.1006/bbrc.1994.2117

197. Kakinuma Y, Miyauchi T, Yuki K, Murakoshi N, Goto K, Yamaguchi I. Novel molecular mechanism of increased myocardial endothelin-1 expression in the failing heart involving the transcriptional factor hypoxia-inducible factor- $1 \alpha$ induced for impaired myocardial energy metabolism. Circulation. 2001;103:2387-2394. doi:10.1161/01.cir.103.19.2387

198. Takanashi M, Miyauchi T, Kakinuma Y, Goto K, Yamaguchi I. Establishment of hypoxia inducible factor- $1 \alpha$ overexpressing cells that produce endothelin-1. J Cardiovasc Pharmacol. 2004;44: S268-73. doi:10.1097/01.fjc.0000166282.01034.8f

199. Piuhola J, Kerkelä R, Keenan JI, Hampton MB, Richards AM, Pemberton CJ. Direct cardiac actions of erythropoietin (EPO): effects on cardiac contractility, BNP secretion and ischaemia/ reperfusion injury. Clin Sci (Lond). 2008;114:293-304. doi:10.1042/CS20070229

200. Ren A, Yan X, Lu H, et al. Antagonism of endothelin-1 inhibits hypoxia-induced apoptosis in cardiomyocytes. Can J Physiol Pharmacol. 2008;86:536-540. doi:10.1139/Y08-051

201. Dhar P, Sharma VK, Hota KB, et al. Autonomic cardiovascular responses in acclimatized lowlanders on prolonged stay at high altitude: a longitudinal follow up study. PLoS One. 2014;9(1): e84274. doi:10.1371/journal.pone.0084274
202. Li Y, Shi L, Wu N, et al. [Effects of hyperbaric oxygen preconditioning on human stress responses during acute exposure to high altitude]. Zhonghua Lao Dong Wei Sheng Zhi Ye Bing Za Zhi. 2015;33(10):731-734.

203. Dhar P, Sharma VK, Das SK, Barhwal K, Hota SK, Singh SB. Differential responses of autonomic function in sea level residents, acclimatized lowlanders at $>3500 \mathrm{~m}$ and Himalayan high altitude natives at $>3500 \mathrm{~m}$ : a cross-sectional study. Respir Physiol Neurobiol. 2018;254:40-48. doi:10.1016/j.resp.2018.04.002

204. Wu L, Tan JL, Wang ZH, et al. ROS generated during early reperfusion contribute to intermittent hypobaric hypoxia-afforded cardioprotection against postischemia-induced $\mathrm{Ca}(2+)$ overload and contractile dysfunction via the JAK2/ STAT3 pathway. $J$ Mol Cell Cardiol. 2015;81:150-161. doi:10.1016/j.yjmcc.2015.02.015

205. Mallet RT, Ryou MG, Williams AG, Howard L, Downey HF. $\beta_{1^{-}}$ Adrenergic receptor antagonism abrogates cardioprotective effects of intermittent hypoxia. Basic Res Cardiol. 2006;101 (5):436-446. doi:10.1007/s00395-006-0599-y

206. Müller FU, Lewin G, Baba HA, et al. Heart-directed expression of a human cardiac isoform of cAMP-response element modulator in transgenic mice. J Biol Chem. 2005;280(8):6906-6914. doi:10.1074/jbc.M407864200

207. El Jamali A, Freund C, Rechner C, Scheidereit C, Dietz R, Bergmann MW. Reoxygenation after severe hypoxia induces cardiomyocyte hypertrophy in vitro: activation of CREB downstream of GSK3beta. FASEB J. 2004;18(10):1096-1098. doi:10.1096/fj.03-1054fje

208. Tomita H, Nazmy M, Kajimoto K, Yehia G, Molina CA, Sadoshima J. Inducible cAMP early repressor (ICER) is a negative-feedback regulator of cardiac hypertrophy and an important mediator of cardiac myocyte apoptosis in response to beta-adrenergic receptor stimulation. Circ Res. 2003;93 (1):12-22. doi:10.1161/01.RES.0000079794.57578.F1

209. Schulte JS, Fehrmann E, Tekook MA, et al. Cardiac expression of the CREM repressor isoform CREM-Ib $\triangle \mathrm{C}-\mathrm{X}$ in mice leads to arrhythmogenic alterations in ventricular cardiomyocytes. Basic Res Cardiol. 2016;111(2):15. doi:10.1007/s00395-016-0532-y

210. ASA/JPL-Caltech. Aster Global Digital Elevation Map (GDEM). Available at: https://asterweb.jpl.nasa.gov/images/GDEM-10kmcolorized.png. Accessed February 28, 2021.
Vascular Health and Risk Management

\section{Publish your work in this journal}

Vascular Health and Risk Management is an international, peerreviewed journal of therapeutics and risk management, focusing on concise rapid reporting of clinical studies on the processes involved in the maintenance of vascular health; the monitoring, prevention and treatment of vascular disease and its sequelae; and the involvemen of metabolic disorders, particularly diabetes. This journal is indexed on PubMed Central and MedLine. The manuscript management system is completely online and includes a very quick and fair peerreview system, which is all easy to use. Visit http://www.dovepress. com/testimonials.php to read real quotes from published authors. 